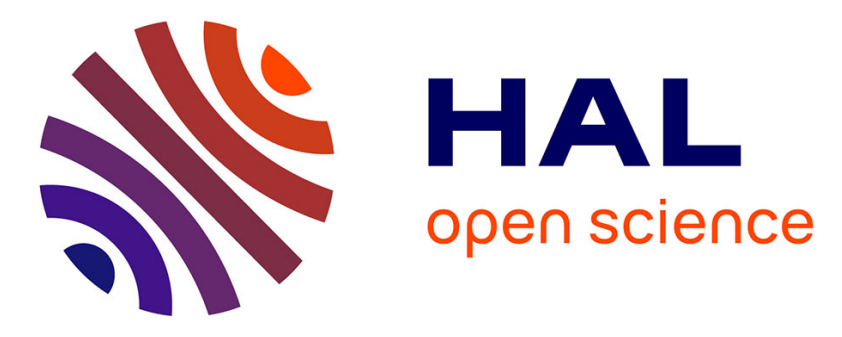

\title{
Bubbles and incentives: an experiment on asset markets
}

Stéphane Robin, Katerina Straznicka, Marie Claire Villeval

\section{To cite this version:}

Stéphane Robin, Katerina Straznicka, Marie Claire Villeval. Bubbles and incentives: an experiment on asset markets. Economic and Political Studies, 2021, 9 (1), pp.68-89. 10.1080/20954816.2020.1839158 . halshs-03033454

\section{HAL Id: halshs-03033454 \\ https://shs.hal.science/halshs-03033454}

Submitted on 19 Jul 2021

HAL is a multi-disciplinary open access archive for the deposit and dissemination of scientific research documents, whether they are published or not. The documents may come from teaching and research institutions in France or abroad, or from public or private research centers.
L'archive ouverte pluridisciplinaire HAL, est destinée au dépôt et à la diffusion de documents scientifiques de niveau recherche, publiés ou non, émanant des établissements d'enseignement et de recherche français ou étrangers, des laboratoires publics ou privés. 


\title{
Bubbles and Incentives: An Experiment on Asset Markets
}

\author{
Stéphane Robin ${ }^{\mathrm{a}}$, Kateřina Strážnická ${ }^{\mathrm{b}}$ and Marie Claire Villeval ${ }^{\mathrm{c}}$ \\ Published in Economic and Political Studies, Special issue on Behavioral and Experimental Economics \\ for Policy Making 9(1), 68-89. https://doi.org/10.1080/20954816.2020.1839158
}

\begin{abstract}
We explore the effects of competitive incentives and of their time horizon on the evolution of both asset prices and trading activity in experimental asset markets. We compare $i$ ) a no-bonus treatment based on Smith, Suchanek and Williams (1988); ii) a short-term bonus treatment in which bonuses are assigned to the best performers at the end of each trading period; iii) a long-term bonus treatment in which bonuses are assigned to the best performers at the end of the 15 periods of the market. We find that the existence of bonus contracts does not increase the likelihood of bubbles but it affects their severity, depending on the time horizon of bonuses. Markets with long-term bonus contracts experience lower price deviations and a lower turnover of assets than markets with either no bonuses or long-term bonus contracts. Short-term bonus contracts increase price deviations but only when markets include a higher share of male traders. At the individual level, the introduction of bonus contracts increases the trading activity of males, probably due to their higher competitiveness.
\end{abstract}

Keywords: Asset market, bubbles, incentives, bonuses, risk attitudes, experiment.

JEL codes: C92, M52

a Univ. Grenoble Alpes, CNRS, INRA, Grenoble INP*, GAEL, 38000 Grenoble, France, stephane.robin@univ-grenoble-alpes.fr.

b Clermont Université, Université d'Auvergne, EA 3849, Centre de recherche clermontois en gestion et management, CRCGM, BP 10448, F-63000 Clermont-Ferrand, France. E-Mail: katerina.straznicka@udamail.fr.

${ }^{c}$ University of Lyon, Lyon, F-69007, France ; CNRS, GATE Lyon Saint-Etienne, Ecully, F-69130, France. IZA, Bonn, Germany. E-Mail: villeval@gate.cnrs.fr, corresponding author.

We are thankful for helpful suggestions to participants at the $4^{\text {th }}$ EWEBE workshop in Barcelona, the $1^{\text {st }}$ SEBA-GATE workshop in Beijing, the CIRPEE workshop on Advances in Experimental Economics at the University of Paris I, the INAPOR Workshop in Nice, and at a seminar at the University of Bern. We thank V. Lei for providing us the computer software used in this experiment and V. Verdier for helpful research assistance. Financial support from Agence Nationale de la Recherche (ANR BLAN07-3_185547, EMIR project) is gratefully acknowledged. 


\section{INTRODUCTION}

Financial bubbles in asset markets - defined as 'trade in high volume at prices that are considerably at variance from intrinsic value' (King et al., 1993) - have serious consequences for the economy as a whole. Mispricing generates severe distortions in the allocation of capital and bubble crashes destroy a large amount of wealth and have adverse repercussions for the wider economy, as illustrated by the current global financial crisis. This phenomenon is in contrast with the efficient market hypothesis where actual prices reflect the asset's fundamental value (Fama, 1970). Indeed, if traders share the same priors about an asset's value, there should be no gain to trade (Tirole, 1982). ${ }^{1}$ Speculation then relies on inconsistent plans and should be ruled out by rational expectations. The responsibility of traders' compensation schemes has been pointed out as a potential cause of speculation and increased volatility of stock markets. Traders are often perceived as trading at excessively high frequency and as taking excessive risks in the markets in the pursuit of ever-greater bonuses. In particular, after the major financial crisis of 2008 the Pittsburgh meeting of the Group of twenty finance ministers and central bank governors in September 2009 has insisted on the importance of reforming traders' compensation practices in order to support financial stability (G20 Leaders, 2009). ${ }^{2}$

The main aim of this paper is to study whether traders' competitive incentives contribute to the emergence and the severity of bubbles in asset markets. We analyze whether the introduction of competitive bonus contracts in traders' compensation packages influences the occurrence of bubbles and crashes. We manipulate the time-horizon of the bonuses and the portfolio valuation in

\footnotetext{
${ }^{1}$ The no-trade theorem states that when rational and risk-neutral traders participate in a market with ex ante Paretooptimal allocation and receive private information, they can still never agree to any trade (Milgrom and Stokey, 1982). 2 Its final declaration stated: "Excessive compensation in the financial sector has both reflected and encouraged excessive risk taking. Reforming compensation policies and practices is an essential part of our effort to increase financial stability. We fully endorse the implementation standards of the FSB aimed at aligning compensation with long-term value creation, not excessive risk-taking..." (G20 Leaders, 2009)
} 
their calculation to measure their influence on the efficiency of asset markets. Precisely, we test whether mispricing is increased by the distribution in each period of short-term bonuses for which portfolios are valued at the current market price. And we test whether it is decreased by the payment of long-term bonuses at the end of the market when portfolios are valued at their fundamental value.

Since individual survey data on traders' compensation schemes are not easily accessible, we privilege here an experimental approach. This allows us to relate potential deviations from the assets' fundamental value to the introduction of various types of bonuses in traders' compensation schemes. Several studies have considered the effect of compensation schemes on mispricing in experimental asset markets. These studies are based on the multi-periods asset-life markets experimental design introduced in Smith, Suchamek and Williams (1988). James and Isaac (2000) and Isaac and James (2003) introduce tournaments whose winners are determined at the end of the last trading period. They find that "beating-the-market" incentives increase mispricing. In contrast with their design, in our experiment market prices are a component of the performance measure that conditions the assignment of bonuses. Cheung and Coleman (2014) show that league-table incentives that are paid each four periods on the basis of the recent growth in the value of the traders' portfolio amplify the price deviations above the intrinsic value of the assets. This effect increases with traders' experience and is stronger when the fundamental value of assets is declining over time than in a constant-value environment. In contrast with these studies, we manipulate the frequency at which bonuses are distributed and we conduct our analysis both at the market and at the individual levels to better understand traders' behavior in reaction to incentives. In particular, we study the role played by traders' risk preferences on the dynamics of prices.

Holmen et al. (2014), Klenlercher et al. (2016) and Baghestanian et al. (2017) study whether traders' decisions and the resulting market dynamics are affected by option-like incentives in which 
traders receive a guaranteed base salary and a bonus proportional to market earnings. In Holmen et al. (2014) and Klenlercher et al. (2016), excessive risk taking resulting from such incentives is the main driver for bubbles. Baghestanian et al. (2017) show that the control of traders by independent investors through liquidity provision fails to mitigate bubbles. Unlike these studies, there is no guaranteed salary for traders in our design. Instead, traders' earnings are the sum of asset dividend and market profit plus a bonus for the best performer(s). Our experimental design differs from that used in these three studies from several other respects.

Precisely, our design consists of three treatments of an asset market game. As in Isaac (2000) and Isaac and James (2003), our baseline treatment ("no-bonus treatment") mostly replicates the design of Smith, Suchanek and Williams (1988) (SSW, hereafter). Eight agents are endowed with an equal initial endowment in cash and shares and they can trade assets in a 15-periods asset-life market. Assets pay the same dividend to each trader in each period and the dividend is the only source of intrinsic value. The structure of dividends and the evolution of the fundamental value of the asset are common knowledge from the very beginning of the game. In contrast with the predictions of the no-trade theorem, the previous experimental literature has shown that trading is important in these markets. Prices typically diverge from the fundamental value of the assets, starting below the fundamental value and quickly rising above it until a crash occurs. ${ }^{3}$

In order to measure how these results are affected by the nature of incentives, our two other treatments introduce bonus contracts. In the short-term bonus treatment, the top three performers

\footnotetext{
${ }^{3}$ Since the seminal work of SSW, numerous treatment manipulations of the original design have been tested: see Palan, (2009), Noussair and Tucker (2013), Powell and Shestakova (2016) or Nuzzo and Morone (2017) for a survey; King et al. (1993) on the influence of experience; Lei et al. (2001) on non-speculative bubbles; Noussair et al. (2001) on assets with constant fundamental values; Haruvy and Noussair (2006) on the effect of short-selling on mispricing; Oechssler et al. (2011) and Sutter et al. (2012) on the role of information; Cheung and Palan (2014) on the improvement permitted by team decision-making; Breaban and Noussair (2017) on the role of emotions. Mispricing is robust to most of these manipulations, except an increased experience within the same group of traders, suggesting a responsibility of the lack of common expectations in bubble formation (see for instance Van Boening et al., 1993, or more recently on the same topics Cheung et al., 2014).
} 
receive in each period a bonus whose value depends on the traders' performance rank. In the longterm bonus treatment, bonuses are awarded to the top three performers as measured after the 15 market periods have been completed. In the short-term bonus treatment, the trader's performance is based on his or her profit in the current period and on the change of his or her portfolio's value between the previous and the current period assessed at the current period average market price. In the long-term bonus treatment, the traders' performance is assessed on the basis of the profits obtained over the life of the market. This manipulation allows us to test how different types of incentives influence market efficiency.

Our findings show that the introduction of bonus contracts does not increase the likelihood of bubbles in the asset markets but it affects their severity. The markets with long-term bonus contracts experience less price deviations, smaller bubble amplitude and less asset turnover than the markets with either short-term bonus contracts or no-bonus contracts. Overall, our results reveal that the nature of incentives influences mispricing notably through a differentiated impact on the behavior of male traders.

The remainder of this paper is organized as follows. Section 2 surveys the related literature. Section 3 presents our experimental design, the procedures and our conjectures. Section 4 develops the experimental findings. Last, Section 5 discusses the results and concludes.

\section{RELATED LITERATURE}

Very few experimental studies have examined how competitive incentives affect the dynamics of asset markets. ${ }^{4}$ As mentioned in the introduction, Holmen et al. (2014) study whether option-like incentives affect traders' behavior and the dynamics of markets. This incentive scheme increases risk-taking and asset prices. Using a similar design, Klenlercher et al. (2016) analyze the impact of

\footnotetext{
${ }^{4}$ This is also true in the field of personnel economics where the impact of tournament contracts has been studied within organizations but not outside firms (see for example McLaughlin, K.J., 1988, for a survey).
} 
bonus caps and penalties. Both mechanisms mitigate overpricing. In a new extension of the previous studies, Baghestanian et al. (2017) endogenize liquidity provision through a principalagent relationship between investors and traders. This control on traders' risk-taking fails to mitigate price increasing. Investors provide excessive liquidity provision, which increases trading at higher prices even under the bonus cap.

Our study uses a different design than these previous studies and is more in line with the work of James and Isaac (2000). James and Isaac (2000) have provided the first test of the effect of tournament incentives on bubble formation, by means of a within-subject experiment based on the design of SSW (1988). In their experiment, nine traders participate in six successive 15 periodslife asset markets, with or without tournaments. The tournament is a 'beat-the-market' incentive scheme: the traders who performed above average at the end of the 15 periods receive a bonus equal to twice the difference between their profit and the average profit; those who perform below average receive a flat payment. The results indicate that tournaments increase mispricing. In a follow-up study, Isaac and James (2003) show that when the proportion of traders with a tournament contract is reduced sufficiently, the impact of tournaments on mispricing disappears. In contrast with this approach, we use a between-subject design to avoid the potential order effects of a within-subject design. In addition, at the end of the market traders earn the value of their cash balance and in one of our treatments, market prices are a component of the performance measure that conditions the assignment of bonuses. This is unlike the 'beat-the-market' principle used by James and Isaac. Another difference is that traders know the bonuses they can earn from the very beginning of the session.

Rather than paying a one-time bonus at the end of session, Cheung and Coleman (2014) introduce league-table incentives consisting of bonuses assigned at evenly-timed intervals over the life of the market on the basis of the 'year-on-year' growth in the paper value of the traders' asset holdings. 
The three top-ranked traders receive an inflow amounting to double the payment they would have received in the baseline condition; the three middle-ranked traders receive an inflow amounting to the same payment as in the baseline condition; the last three traders receive nothing. Cheung and Coleman (2014) also study the influence of experience and they compare markets in which the fundamental value of the asset declines over time with markets in which the fundamental value is constant. They find that in the constant-value environment, the effect of incentives is mild; in contrast, in the declining-value environment, mispricing is greatly exacerbated by incentives. Even in experienced markets, prices climb to levels clearly indicative of speculation and bubbles do not always crash.

In contrast with this study, we manipulate the frequency at which bonuses are distributed to compare the impact of short-term versus long-term incentives. Moreover, we analyze our data not only at the market level but also at the individual level. In particular, we study the role played by traders' risk preferences on their trading behavior and on the resulting dynamics of prices under the different incentive schemes.

We suspect that risk attitudes and gender may have a different impact when bonuses are offered. That is why we control for these two variables in our design. The literature studying the influence of individual risk preferences on the efficiency of markets delivers contrasted results. On the one hand, Ang and Schwarz (1985) find that less risk-averse markets show greater price volatility but converge quicker to the equilibrium price. On the other hand, Fellner and Maciejovsky (2007) find that the higher the degree of risk aversion of traders, the lower the market activity. Last, Güth et al. (1997) find that in markets with both informed and uninformed agents, risk attitudes do not explain portfolio structures. Our experiment should provide additional evidence on this relationship. As regards the impact of tournaments, Bronars (1986) has shown theoretically that risk-neutral agents allocate too much time to safe projects and that frontrunners limit risks while 
underdogs increase risk-taking in sequential tournaments. Risk-taking may act as a substitute for effort (Hvide, 2002). Agents adopt high-risk-prospects when prizes and spread of prizes are high (e.g., Becker and Huselid, 1992; Gaba and Kalra, 1999; Lee, 2004), when only a top few win (Gaba and Kalra, 1999), and depending on the relative position in interim reports (e.g., Nieken and Sliwka, 2010). Studies in financial economics have also shown that relative performance objectives increase the riskiness of investment strategies (Palomino, 2005) and that investment fund managers paid on a yearly basis adjust the risk they take in the latter part of the year to their relative position mid-year. ${ }^{5}$ About the expected gender effect, Eckel and Füllbrunn (2015) have found that a higher fraction of female traders in asset markets reduces the likelihood of bubble formation, and they have identified an inverse relationship between this fraction of female traders and the magnitude of bubbles, based on a meta-analysis of 35 markets. They also found that females have lower forecasts of prices. Also, regarding incentives, previous research has shown that males are more attracted by competition (Niederle and Vesterlund, 2007) and increase more their effort in competitive environments than females (Gneezy et al., 2003). Therefore, we control whether the impact of bonus contracts on the dynamics of asset markets is affected by traders' risk preferences and gender.

\section{EXPERIMENTAL DESIGN, PROCEDURES, AND PREDICTIONS}

Our between-subjects experiment consists of three treatments that are described successively. Then, we develop the procedures before introducing our behavioral conjectures.

\footnotetext{
${ }^{5}$ There is, however, no consensus on which managers take riskier positions. Some find that those who increase the fund volatility or portfolio risk more in the latter part of the year are the mid-year losers (e.g., Brown et al., 1996; Chevalier and Ellison, 1997; Kempf and Ruenzi, 2008); others find that interim winners are more likely to gamble since they expect that the underdogs will try to catch up (e.g., Busse, 2001; Qui, 2003; Taylor, 2003).
} 


\subsection{The treatments}

\section{The no-bonus treatment}

The no-bonus treatment replicates most aspects of the SSW's (1988) procedure. ${ }^{6}$ It consists of a computerized continuous double auction market that allows eight participants to trade risky assets in real time in a sequence of 15 market periods. Each market period lasts 240 seconds. At the beginning of the experiment, each trader is given both an initial portfolio of 10 asset units and a cash endowment of 20,000 Experimental Currency Units (ECU, hereafter). The initial endowment of liquidity can be considered as a loan that has to be paid back at the end of the experiment. ${ }^{7}$ The cash initial endowment is set at a high level in order to minimize the influence of injection of liquidity in the short-term bonus treatment. Trades follow continuous auction rules. ${ }^{8}$ Traders are allowed to trade one asset at a time and the order book has a depth of one (i.e., posted orders are automatically erased by better bids and asks). Short sells are not allowed. Traders can buy assets as long as their liquidity permits it; they are not granted credit. They all receive exactly the same initial endowments in shares and liquidity, and thus have identical ex ante earning opportunities. We do this to eliminate any possibility that the liquidity and asset unit composition of a trader's initial endowment biases his or her position in the bonus contracts treatments.

At the end of each period, each asset unit generates a stochastic dividend to its current owner. The actual dividend value is the same for all assets in the market and for everyone in a given period.

\footnotetext{
${ }^{6}$ There are three main differences with SSW (1988). First, we do not have traders that differ in the allocation of shares and cash endowment. Second, we do not allow traders to bypass the stopping rule by voting to end a trading period before the maximum time has elapsed. Third, there is no rank queue for offers that do not improve the current posted offers. Further literature on experimental asset markets has shown that these differences do not alter the main conclusions of SSW (1988).

${ }^{7}$ If a subject ends the game with a loss, this loss is deducted from her show-up fee and this is common information. If the loss is higher than the show-up fee, we do not ask for any reimbursement. The market initial endowment in liquidity allows a trader to purchase more than $2 / 3$ of the total stock of assets at the initial fundamental value. This large initial endowment was chosen in order not to constrain purchases in the market.

${ }^{8}$ The continuous auction rules are explained in details and their properties are commented in Friedman (1993).
} 
The dividend payments are randomly drawn from a uniform distribution $(0,8,28,60$ ECU). Therefore, the expected value of each asset is 24 ECU in each period. The earnings generated by dividend payments in each period are added to the owner's liquidity at the end of the period. The dividend structure is common knowledge.

Assuming that traders are risk neutral and using backward induction, the asset's fundamental value is equal to the expected total future flow of dividends. In any period, it is calculated as the number of dividend draws remaining until the end of the sequence of 15 periods times the expected dividend value (24 ECU). Thus, at the beginning of the sequence the fundamental value of each asset unit is $360 \mathrm{ECU}\left(15^{*} 24\right)$, while it is only $24 \mathrm{ECU}$ at the beginning of the fifteenth period. When the fifteenth period is over, the asset's value equals zero. There is no buy-out option. Figure 1 displays the evolution of the asset's fundamental value over time.

[Insert Figure 1 about here]

The dividend structure is made common information and precautions are taken to ensure that participants plainly understood this structure. ${ }^{9}$ The traders' current liquidity and asset holdings are displayed on the screens and are automatically updated after each transaction and after each dividend payment. Once a period is over, traders receive summary information on the amount of the dividend payment drawn for this period, the total amount of asset holdings and liquidity. During

\footnotetext{
${ }^{9}$ The calculation of the asset fundamental value is explained and exemplified in the instructions. Together with the instructions participants receive a table indicating the fundamental value of each asset unit in each period. (see Appendix A).
} 
a period, a history box displays all the transactions concluded in the market and their respective price since the beginning of the period. ${ }^{10}$

In a period, earnings are computed as the evolution of the liquidity during this period, i.e. the revenues generated by the stock sales minus the cost of stock purchases. They are augmented at the end of each trading period with the dividend earnings (the dividend value times the stock of asset holdings at the end of the period). Indeed, there are two sources of profits for the traders. The first one is related to both the trading activity and the evolution of stock prices. The other one consists of the dividend earnings. Therefore, the trader $i$ 's profit in period $t$ writes as follows:

$$
\text { Profit }_{i t}=\left(\text { stock sales revenues }_{i t}-\text { stock purchase costs }_{i t}\right)+\left(\text { assets }_{i t} * \text { dividend }_{t}\right)
$$

\section{The short-term bonus treatment}

The short-term bonus treatment implements a rank-order tournament between the traders in each trading period. Precisely, at the end of each period the performance of the traders is compared. The three traders who realized the highest performance in the period earn a bonus on top of their profit of the period. Trader $i$ 's performance in period $t$ is calculated as follows:

$$
\begin{aligned}
& \text { Performance }_{i t}=\text { Profit }_{i t}+\left[\left(\text { assets }_{i t} * \text { average market price }{ }_{t}\right)\right. \\
& \text { - } \left.\left.\text { assets }_{i(t-1)} \text { *average market price }_{(t-1)}\right)\right]
\end{aligned}
$$

The first term represents the trader's profit as explained in equation (1). The second term captures the variation in the value of the trader's portfolio between the end and the beginning of the current period calculated at the market price. The value of the trader's portfolio at the beginning of a period equals the number of his or her asset holdings at the beginning of the period (namely the number of his asset holdings at the end of the previous period) multiplied by the average market price of

\footnotetext{
${ }^{10}$ At the end of a period, the participants have to record manually on an inventory and payoff table the evolution of their liquidity during the current period, the number of asset units owned at the end of the period, the amount of the dividend, and the resulting earnings for the period. The reason we asked them to do so is to make them take into consideration the impact of their market behavior on the evaluation of their gains or losses.
} 
all concluded transactions in the market during the previous period. The value of his or her portfolio at the end of the period equals the number of her asset holdings at the end of the period multiplied by the average market price of all concluded transactions within the current period. This representation of performance takes into account both the activity of the trader in the market and his or her ability to manage his or her capital in given short-term market conditions. ${ }^{11}$

In each period, the trader who realized the highest performance in the period receives a bonus of 240 ECU. The trader who realized the second highest performance receives a bonus of 168 ECU. The bonus of the trader who realized the third highest performance amounts to $72 \mathrm{ECU}$. The highest bonus corresponds to the expected dividend generated by 10 asset units during one period. The second (third, respectively) bonus represents $70 \%$ (30\%, resp.) of the value of the highest bonus. The bonus is added to the traders' liquidity before the beginning of the next period. These amounts have been determined arbitrarily, such as to provide a salient additional incentive to realize a high performance without introducing too many additional liquidities in the market throughout the session given the initial cash endowment. ${ }^{12}$

\section{The long-term bonus treatment}

The long-term bonus treatment also introduces a rank-order tournament between the traders but here, the traders' performances throughout the session are compared at the end of the 15 periods. The three traders with the highest total performance earn a bonus which value depends on their

\footnotetext{
${ }^{11}$ In period 1, as there is no previous period of play, the performance accounts only for the portfolio development during the first period valued at the average market price of this period.

12 Indeed, this injection of liquidity could bias the comparison between the short-term bonus treatment and the other treatments for which the total amount of liquidity is kept constant throughout the session. Existing literature has shown that the level of liquidity can influence the occurrence and magnitude of price bubbles (see Caginalp et al., 1998, 2001; see also Kirchler et al., 2012). We assume, however, that if this effect can exist, it should be very limited. Indeed, the maximum amount of bonuses a trader could potentially receive is $3,600 \mathrm{ECU}$, which represents $18 \%$ of the initial endowment in liquidity. In fact, $i$ ) no trader uses all his cash to trade; ii) this cash is injected period by period and not at the very beginning of the game; iii) it is not the case that the same traders receive the bonuses repeatedly at each period (see the final results sub-section); so there is no concentration of additional liquidities in the hands of only a few traders.
} 
rank. The best performer receives a bonus of 3,600 ECU, the second best performer receives a bonus of 2,520 ECU, and the third one a bonus of 1,080 ECU. The total amount of bonuses distributed is the same as in the short-term bonus treatment. Performance is measured as the sum of profits obtained during the 15 periods of the game. In contrast with the short-term bonus contracts, the portfolios are here valued at their fundamental value, as the current value of the asset holdings at the end of the market life is zero.

\subsection{Procedures}

The experiment was conducted in the laboratory of the Groupe d'Analyse et de Théorie Economique, Lyon, France. 256 subjects were recruited via the ORSEE software (Greiner, 2015) from undergraduate classes at the local business and engineering schools. None of them had already participated in asset market experiments. 32 sessions with eight participants each were conducted (12 sessions with the no-bonus treatment, 10 sessions with the short-term bonus treatment, and 10 with the long-term bonus treatment).

Upon arrival, the participants were randomly assigned to a computer terminal by drawing a tag from an opaque bag. They participated first to a test of risk attitudes using the Holt and Laury (2002) procedure (see Appendix A). This allows us to control for the impact of the distribution of traders' risk attitudes on the dynamics of trades. ${ }^{13}$ Then, the instructions of the game (see Appendix A) were read aloud and the subjects' understanding was checked. Subjects played a five-minute long practice period to familiarize themselves with the trading rules and the calculation of earnings. After all the subjects' questions were answered in private, the subjects played the 15 periods of the

\footnotetext{
13 Subjects make ten successive choices between two paired lotteries, "option A" and "option B". The payoffs for option $A$ are either $€ 2$ or $€ 1.60$. The riskier option $B$ pays either $€ 3.85$ or $€ 0.10$. They reported an average risk-aversion switching point of 6.50. The corresponding number for females was 6.70 .
} 
asset market game without interruption. The game was computerized using the Z-Tree platform (Fischbacher, 2007). Once the 15 periods were completed, the subjects answered a brief demographic questionnaire and were asked to self-report their level of knowledge in statistics and finance on a Likert-type scale graduated from 0 to 5 . Then, they proceeded to a separate payment room where they played in private the risk elicitation lottery by rolling a ten-sided dice. Payoffs were paid in cash. Participants earned on average $€ 22$, including a $€ 5$ show-up fee. On average, a session lasted two and a half hours.

\subsection{Behavioral predictions}

If we assume rational behavior, common knowledge of rational behavior, and risk neutrality, traders should not trade in the market, as they are perfectly informed on the expected value of their asset in each period of the market. However, previous literature has shown that individuals use to trade and that mispricing is frequent. Therefore, we turn now on behavioral predictions. Our conjectures are related to the presence of bonuses. We anticipate that the presence of short-term incentives favors higher risk-taking and a higher trading activity than long-term incentives. Indeed, the willingness to get a bonus may motivate the players to trade more in each period. As the variation in the value of the trader's portfolio is a crucial determinant of the likelihood of earning a bonus, we anticipate that some players may promote the rise in prices in order to increase the value of their portfolio. Conversely, they may resist against falling prices, which is the expected trend given the evolution of the assets' intrinsic value. ${ }^{14}$ This should lead to larger price deviations from the fundamental value. In contrast, the long-term bonuses should incite the players to consider from

\footnotetext{
${ }^{14}$ Everything else remained equal, trader's performance explained in equation (2) increases with asset prices.
} 
the very beginning the whole life of the market all together instead of each period separately, and to focus on the fundamental value of the assets. We formulate the following conjectures:

Conjecture 1: Markets with short-term bonuses are more prone to bubble formation and exhibit larger price deviations from the fundamental value of the assets than markets with no bonuses.

Conjecture 2: Markets with long-term bonuses are less prone to bubble formation and exhibit less mispricing than markets with short-term bonuses or with no bonuses.

\section{RESULTS}

We first present summary statistics on bubble formation by treatment. Then, we provide an econometric analysis of the influence of bonuses on bubble formation. Last, we develop an analysis at the individual level of the links between risk attitudes, trading activity and bonuses.

\subsection{Summary statistics}

We start by studying the occurrence of bubbles. King et al. (1993) define a bubble as "trade at high volumes at prices considerably at variance from intrinsic values". Noussair et al. (2001) consider an operational definition of bubbles where market prices are considerably at variance from the fundamental value of the asset if at least one of the two following conditions is met: $i$ ) the median transaction price in five consecutive periods is at least $15 \%$ above the fundamental value; $i i$ ) the average price is at least two standard deviations of transaction prices greater than the fundamental value for five consecutive periods. We use this definition to characterize the occurrence of a bubble, to which we add a measure of high volume trading. A significant trading activity at prices far from the assets' intrinsic value is indicative of an inefficient market. ${ }^{15} \mathrm{We}$ consider that a period is characterized by a high trading activity when the turnover (i.e., the total quantity of shares

\footnotetext{
${ }^{15}$ A large volume of trades at prices close to the intrinsic value may, conversely, be interpreted as an indication of no bubble formation (Smith et al., 2000).
} 
exchanged in the period divided by the total number of asset holdings -80 in our experiment-) is over 0.15 . Similarly, the whole market of 15 periods is characterized by a high trading activity when the turnover is higher than 2.25. Indeed, when the asset expected payoff is common information, the number of transactions is expected to be low; then, a high turnover is considered as indicating the formation of a bubble. We consider that a bubble has formed during a session when a market satisfies one of the two conditions of Noussair et al.'s (2001) definition and when a high volume of assets has been traded in at least five consecutive periods.

According to this definition, we find that bubbles occurred in four out of twelve sessions (33.33\%) in the no-bonus treatment, in five out of ten sessions $(50 \%)$ in the short-term bonus treatment, and in five out of ten sessions $(50 \%)$ in the long-term bonus treatment. Although the proportion of sessions with a bubble is lower in the no-bonus treatment than in the two other treatments, the difference between the no-bonus treatment and each other treatment is not significant (MannWhitney test, two-tailed, $p=0.439$ ). The introduction of bonuses does not affect the likelihood of bubble formation. This leads to our first Result:

Result 1: Contrary to conjectures 1 and 2, the treatment manipulation does not impact the likelihood of bubble formation on the market.

If the introduction of bonuses does not increase the likelihood of bubbles, it may influence the intensity of distortions. We first consider the evolution of prices and trade volumes over time by treatment, before providing more formal measures of mispricing. Figure 2 displays the evolution of the median price over time by treatment. It shows that the median price is below the fundamental value in the first periods. Then, the median price exceeds it from between the fifth or the seventh period and the last periods. At first sight, the markets with short-term bonuses are associated with larger mispricing than the other treatments. 
[Insert Figure 2 about here]

We also consider the evolution of the total volume of trades over time, as a high trade activity may be associated with mispricing. Figure 3 displays the evolution of the average trading volume by period for different blocks of periods and by treatment. We consider three blocks of periods: periods 1 to 5, periods 6 to 10 , and periods 11 to 15 . The last block on the right aggregates the data from all periods.

\section{[Insert Figure 3 about here]}

Figure 3 shows that the average volume of trades is positive in each block of periods, with a declining time trend. The trading activity is always lower in the long-term bonus treatment than in the two other treatments, especially in the last block of periods. The difference between the longterm bonus treatment and the no-bonus treatment is all the more striking as the quantity of liquidities available is exactly the same in these two treatments throughout the session.

To complement this analysis, we use a range of standard summary measures of bubble severity from the literature on experimental asset markets. These measures include the normalized absolute price deviation (NAPD, hereafter), the normalized price deviation (NPD, hereafter), the amplitude of price deviations, the turnover of assets, and the boom duration. ${ }^{16}$ The $N A P D$ measures the pershare aggregate absolute deviation of the price from the asset fundamental value. A high normalized price deviation reflects high trading volumes and deviations of prices from fundamental values, indicating a market bubble (Haruvy and Noussair 2006). The NPD measure is similar to NAPD, except that instead of considering absolute price deviations, it relies on raw price deviations. It is close to the relative deviation defined by Stöckl et al. (2010) except that our

\footnotetext{
16 The formal definition of these measures can be found in Appendix B. Palan (2009) gives an extensive presentation of the different measures of bubble severity, discusses the relative merits of each measure and presents the value of these measure obtained in previous studies.
} 
measure is normalized over the total sum of asset holdings. A positive NPD indicates that the market on average overvalues the asset, whereas a negative value indicates undervaluation. The amplitude measures the magnitude of overall price changes relative to the asset fundamental value throughout its life (King et al., 1993). Previous literature has shown that high amplitudes are associated with the presence of price bubbles. The turnover captures the intensity of the trading activity in the 15 periods (Smith et al., 1988). Finally, the boom duration represents the number of consecutive periods where the market median price is higher than the fundamental value by at least $20 \%$. Table 1 displays the average values of these measures in each treatment.

Table 1 illustrates a consistent ranking of the three treatments. Mispricing seems to be more severe in the short-term bonus treatment than in the two other treatments. Indeed, for each measure except the turnover, the highest value is found in this treatment. In contrast, the long-term bonus treatment is associated with the lowest NAPD, NPD, amplitude and turnover. In this treatment, the mean boom duration lies in between the values for the two other treatments.

[Insert Table 1 about here]

However, as typical in this type of games, there is a large heterogeneity in the dynamics of prices and market behavior across sessions within each treatment. The within-treatment heterogeneity is easily observable in Tables C1, C2 and C3 in Appendix C that display the same measures session by session. We next proceed to an econometric analysis of the data to analyze how the treatment manipulation and the composition of the pool of traders in each market influence mispricing and trading activity.

\subsection{Econometric analysis}

The determinants of measures of mispricing are estimated with Ordinary Least Squares models in which robust standard errors are clustered at the session level, as each session gives one 
independent observation. We pool the data of each treatment. Table 2 reports these estimates. To characterize the main dimensions of a bubble (price deviations, amplitude and market activity), the independent variables are the normalized absolute price deviation in model (1), the amplitude of bubbles in model (2) and the turnover of assets in model (3).

To measure the impact of the treatment manipulation, the independent variables include dummy variables for each treatment in which bonuses have been introduced. The no-bonus treatment is taken as the reference category. To study whether the within-treatment heterogeneity in mispricing is driven by the traders' characteristics in the market, we include the mean traders' degree of risk aversion as an independent variable. More precisely, we include the average safety index in each session. This index corresponds to the switching point in the Holt and Laury lottery choice task. The higher the average index is, the more risk-averse the traders on average are. We also include the ratio of male traders in each session. Indeed, gender differences have been often observed in financial decisions (Barsky et al., 1997; Powell and Ansic, 1997; Charness and Gneezy, 2007), with males being more overconfident than females (Barber and Odean, 2001) and less risk averse (see Croson and Gneezy, 2009, for a survey). Eckel and Füllbrunn (2015) have found that the formation of bubbles is less likely and the magnitude of bubbles smaller when the fraction of female traders is higher. Therefore, a lower proportion of females in a market may influence our measures. We allow both the mean level of risk attitudes and the gender ratio to vary across treatment by interacting these two variables with the dummy variables for each treatment. Finally, we control for the mean traders' self-reported knowledge in statistics and finance in each session, as one could expect that a better average knowledge in these fields would reduce deviations from the equilibrium, other things equal.

Table 2 shows that, controlling for the characteristics of the pool of traders, the long-term bonus treatment generates lower price deviations (model (1)), a smaller amplitude of bubbles (significant 
only at the $12 \%$ level, see model (2)), and a lower turnover (model (3)) than the no-bonus treatment. Model (3) indicates that the asset turnover is also significantly lower in the short-term bonus treatment than in the no-bonus treatment. Similar regressions using the long-term bonus treatment as the reference category (not reported here but available upon request) indicate that price deviations and the amplitude of bubbles are significantly higher in the short-term bonus treatment than in the long-term bonus treatment (significant at the $1 \%$ level in both cases).

[Insert Table 2 about here]

These findings support our conjecture 2 and are summarized in Result 2:

Result 2: The markets with long-term bonus contracts experience less price deviations, smaller bubble amplitude than the markets with short-term bonus contracts and than the markets with nobonus contracts.

Table 2 also indicates that the composition of the pool of traders influences both mispricing and turnover. Bubbles are more severe and trade activity is more intense in markets with more riskseeking traders. Indeed, there is a significant negative relationship between the mean safety index in the session, NAPD, amplitude and turnover. However, in the long-term bonus treatment, the net impact of risk attitudes on both NAPD and turnover is negligible as the variable interacting the mean risk attitudes and the treatment dummy receives almost the same but positive coefficient as the mean safety index variable (see models (1) and (3)). This suggests that when long-term bonuses are at stake, the positive relationship between the behavior of more risk-seeking traders and mispricing vanishes out almost completely.

Last, we observe that in the no-bonus treatment a higher proportion of male traders is associated with lower NAPD, amplitude of bubbles, and turnover (in contrast with the findings of Eckel and Füllbrunn, 2015). However, the gender composition of the pool of traders has a neutral net impact 
in the long-term bonus treatment. And in the short-term bonus contracts, a higher ratio of male traders generates a net positive impact on NAPD and asset turnover. A possible interpretation is related to the fact that bonus contracts are competitive incentives and that competition is more intense and salient when bonuses are at stake in each period. Previous literature has shown that males are much more competitive than females (Gneezy et al., 2003; Niederle and Vesterlund, 2007). Therefore, male traders may behave more actively in the market when bonuses are at stake -especially when assigned each period- than in the absence of bonuses.

This analysis supports partly our conjecture 1 and leads to the following results:

Result 3: Mispricing is more severe and trade activity is more intense in markets with more risk seeking traders and a higher share of female traders, except when competitive incentives are at stake and especially when bonuses are assigned each period.

Result 4: Markets with short-term bonus contracts tend to exhibit higher price deviations than the markets with no bonuses and the markets with long-term bonus contracts but only when they involve a higher share of male traders.

\subsection{Risk attitudes and individual behavior}

In this sub-section, we study individual trading activity and the subsequent earning of bonuses. Table 3 displays the results of regressions in which the dependent variable is the trader's number of transactions per period. To study whether bonus has a different impact on trading activity depending on the phase of the market (bubble formation, boom and crash), model (1) considers periods 1 to 5; model (2) periods 6 to 10, model (3) periods 11 to 15, and model (4) is for the whole market. These models are estimated by Generalized Least Squares models with robust standard errors clustered at the session level. The independent variables include dummy variables for each 
treatment with bonuses, with the no-bonus treatment taken as the reference category. They also include the trader's individual safety index and gender. These variables are interacted with dummy variables for each treatment with bonuses as we suspect that risk attitudes and gender may have a different impact when bonuses are offered. Finally, two variables capture the self-reported knowledge in statistics and finance.

Table 3 shows that traders have a significantly lower activity in the long-term bonus treatment than in the other treatments and the value of the associated coefficient increases over time. It also shows that more risk averse traders are less active in the market, regardless of the block of periods considered. The introduction of bonuses does not affect the impact of risk aversion on trading activity in the short-term treatment. The (marginal) impact of risk aversion is even sometimes reverted in the long-term bonus treatment, where less risk-averse individuals are less willing to trade. Confirming the analysis at the market level, males trade significantly less than females in almost all blocks of periods. However, the introduction of long-term bonuses annihilates this effect while the net joint effect of short-term bonuses and male gender is positive. An interpretation is that in the presence of short-term incentives, males' competitiveness is increased. Finally, a better knowledge in finance tends to limit trading activity in most blocks of periods.

[Insert Table 3 about here]

These findings are summarized in the following results:

Result 5: At the individual level, controlling for the effect of risk preferences, competitive incentives -especially short-term bonuses- increase male traders' activity.

Finally, we study whether the degree of risk aversion and gender predict the bonuses earned by the traders in the market in the short-term and the long-term bonus treatments. Table 4 reports the 
estimates of four ordered probit models with robust standard errors clustered at the market level in which the dependent variable is the amount of the bonus received in each period in the short-term bonus treatment. The ordered probit model is justified since individuals can earn either no bonus or one of three possible bonuses. Model (1) corresponds to periods 1 to 5 , model (2) to periods 6 to 10 , model (3) to periods 11 to 15 , and model (4) is for the whole market (periods 1 to 15 ). Model (5) in Table 4 analyzes the individual determinants of the receipt of bonuses in the long-term bonus treatment. It is also estimated by means of an ordered probit model with clustering at the session level. The independent variables in all models are the trader's individual safety index, gender, and self-reported knowledge in statistics and in finance.

Models (1) and (2) identify a significant relationship between the trader's risk attitude and gender and the bonuses earned in the first ten periods of the short-term bonus treatment (confirmed by model (4) for the whole market). In this block of periods, both a higher degree of individual risk aversion and being a male trader are associated with a higher probability to earn higher bonuses.

[Insert Table 4 about here]

In contrast, risk attitudes and gender do not affect the amount of bonuses earned in the last five periods. This may result from the fact that this phase of the market corresponds to bubble bursts and it is quite chaotic both for prices and transactions. Players with a higher degree of risk aversion and higher competitiveness are better able to benefit from the market opportunities. Including the volume of assets traded by the individual in the regressions does not affect the probability of receiving bonuses (regressions available upon request). Finally, we do not observe any significant impact of risk attitudes and gender on the receipt of bonuses in the long-term bonus treatment. This leads to our final result:

Result 6: Risk-averse traders and male traders are more likely to earn bigger bonuses in the shortterm bonus treatment, but not in the long-term bonus treatment. 


\section{CONCLUSION}

This paper has explored the effects of various incentive contracts for traders on the evolution of prices and on trading activity in experimental asset markets. Consistent with the previous literature, our treatment with no bonus exhibits active trading and persistent deviations of prices from the assets' fundamental values. If competitive incentives do not increase the likelihood of bubbles, the markets with long-term bonuses experience the lowest price deviations, amplitude and turnover of assets. Mispricing and turnover of assets are even smaller than in the markets with no bonuses. This is in contrast with the conclusions of Isaac and James (2000, 2003), probably due to the use of a different rule for selecting the winners of the tournament. The markets with short-term bonuses experience higher price deviations, amplitude and boom duration than the two other types of markets. Moreover, mispricing is less severe and trade activity is less intense in markets with a higher share of risk-averse traders and of male traders. The last point seems in contrast with Eckel and Füllbrunn (2015). However, the impact of gender is reverted in the presence of short-term bonus contracts. Male traders react more to the introduction of competitive incentives in each period than female traders. Therefore, short-term bonus contracts are associated with significantly higher price deviations than the no-bonus contracts if the share of male traders increases. This is consistent with previous research showing that males are more attracted by competition (Niederle and Vesterlund, 2007) and increase more effort in competitive environments than females (Gneezy, Niederle and Rustichini, 2003). Overall, our results reveal that the nature of incentives influences mispricing notably through a differentiated impact on the behavior of male traders.

Although we are cautious not extrapolating our results due to the heterogeneity of behavior across markets, they provide some evidence that the rules for determining traders' compensation matter in the evolution of prices and trade volumes. In particular, the long-term bonuses contribute to reduce market inefficiency by reducing the volume of trades and mispricing probably because these 
bonuses reinforce the assets' final fundamental value as a focal point from the very beginning of the market, while the short-term bonuses make bonuses and current prices more salient than the fundamental value of the assets. This reveals the importance of the reference point introduced by compensation policies on behavior.

Previous studies report that experience (Dufwenberg et al., 2005), detailed exposure of the fundamental value evolution (Lei and Vesely, 2009), context presentation (Kirchler et al., 2012) or public knowledge on appropriate training (Cheung et al., 2014) reduce the occurrence and the severity of bubble in experimental asset markets. Nevertheless, the creation of bubbles in an environment where traders are informed from the beginning of the evolution of the fundamental value of the assets remains an interesting research topic for economists. Testing whether the composition of the pool of traders affects the dynamics of trades and prices on the markets, we have found that mispricing is more severe and trading activity is more intense in markets where the pool of traders is on average less risk-averse. The introduction of short-term bonuses increases the impact of gender on trading behavior and on mispricing, possibly due to the reinforcing effect of these incentives on males' competitiveness. A potential implication of these findings is that educating individuals in risk management could contribute to reduce the severity of distortions in asset markets.

Several extensions could be thought of. In our experiment the bonus was assigned based on relative performance. A first extension would consist of analyzing the effect of bonuses based on absolute performance or on group performance. Another extension could consist of measuring how a richer set of information (including for example the distribution of performances in the period) would affect market behavior. This is left for further investigation. 


\section{REFERENCES}

Ang, J.S., Schwartz, T. (1985). Risk aversion and information structure: An experimental study of price variability in the securities markets. Journal of Finance 40, 825-844.

Baghestanian, S., Gortner, P., Massenot, B. (2017), Compensation Schemes, Liquidity Provision, and Asset Prices: An Experimental Analysis, Experimental Economics, 20(2) 481-505.

Barber, B.M., Odean, T. (2001). Boys Will Be Boys: Gender, Overconfidence, and Common Stock Investment. The Quarterly Journal of Economics 116 (1), 261-292.

Barsky, R., Juster, F., Kimball, M., Shapiro, M. (1997) Preference Parameters and Behavioral Heterogeneity: An Experimental approach in the Health and Retirement Study. The Quarterly Journal of Economics 112 (2), 537-579.

Becker, B.E., Huselid, M.A. (1992). The Incentive Effects of Tournament Compensation Systems. Administrative Science Quarterly 37 (2), 336-350.

Breaban, A., Noussair, C.N. (2017). Emotional state and market behavior. Review of Finance 22(1), 279-309.

Bronars, S. (1986). Strategic Behavior in Tournaments, Texas A\&M University, Austin, mimeo.

Brown, K.C., Harlow W.V., Starks, L.T. (1996). Of Tournaments and Temptations: An Analysis of Managerial Incentives in the Mutual Fund Industry. Journal of Finance 51 (1), 85-110.

Busse, J.A. (2001). Another Look on Mutual Funds Tournaments, Journal of Financial and Quantitative Analysis 36(1), 2001, 53-73.

Caginalp, G., Porter, D.P., Smith, V.L. (1998). Initial Cash/Asset Ratio and Asset Prices: An Experimental Study, Proceedings of the National Academy of Sciences 95, 756-761.

Caginalp, G., Porter, D.P., Smith, V.L. (2001). Financial bubbles: excess cash, momentum, and incomplete information, Journal of Psychology and Financial Markets 2(2), 80-99.

Charness, Gary B., Gneezy, U. (2007). Strong Evidence for Gender Differences in Investment. University of California at Santa Barbara, Economics Working Paper Series, Department of Economics, UC Santa Barbara. http://www.escholarship.org/uc/item/428481s8.

Cheung, S., Palan, S. (2012). Two heads are less bubbly than one: team decision-making in an experimental asset market, Experimental Economics 15(3), 373-397.

Cheung, S., Coleman, A. (2014). Relative Performance Incentives and Price Bubbles in Experimental Asset Markets. Southern Economic Journal 81(2), 345-363.

Cheung, S. L., Hedegaard, M., Palan, S. (2014). To See Is To Believe: Common Expectations in Experimental Asset Markets. European Economic Review 66(C), 84-96.

Chevalier, J., Ellison, G. (1997). Risk taking by mutual funds as a response to incentives, Journal of Political Economy 105, 1167-1200.

Croson, R., Gneezy, U. (2009). Gender Differences in Preferences. Journal of Economic Literature 47 (2), 448-474.

Dufwenberg, M., Lindqvist, T., Moore, E. (2005). Bubbles and Experience: An Experiment, American Economic Review, 95, 1731-1737. 
Eckel, C.C., Füllbrunn, S.C. (2015). Thar "SHE" blows? Gender, Competition, and Bubbles in Experimental Asset Markets. American Economic Review 105(2), 906-920.

Fama, E.F. (1970). Efficient Capital Markets: A Review of Theory and Empirical Work, The Journal of Finance, 25, 383-417.

Fellner, G., Maciejovsky, B. (2007). Risk attitude and market behavior: Evidence from experimental asset markets, Journal of Economic Psychology, 28, 338-350.

Fischbacher, U. (2007). Z-Tree: Zurich Toolbox for Ready-made Economic Experiments, Experimental Economics, 10, 171-178.

Friedman D. (1993). The Double Oral Auction Market Institution: A Survey, In The Continuous Double Auction Market: Institutions, Theories, and Evidence, ed. D. Friedman and J. Rust, 326. Reading Mass.: Addison-Wesley.

G20 Leaders (2009). G20 Leaders Statement: The Pittsburgh Summit, September 24-25, 2009, Pittsburgh Retrieved from URL

Gaba, A., Kalra, A. (1999). Risk Behavior in Response to Quotas and Contests, Marketing Science $18(3), 417-434$.

Gneezy, U., Niederle, M., Rustichini, A. (2003). Performance in Competitive Environments: Gender Differences. The Quarterly Journal of Economics, 118, 1049-1074.

Greiner, B. (2015). Subject Pool Recruitment Procedures: Organizing Experiments with ORSEE. Journal of the Economic Science Association 1, 114-125.

Güth, W., Krahnen, J.P., Rieck, C. (1997). Financial markets with asymmetric information: A pilot study focusing on insider advantages, Journal of Economic Psychology 18, 235-257.

Haruvy, E., Noussair, C.N. (2006). The Effect of Short-Selling on Bubbles and Crashes in Experimental Spot Asset Markets, Journal of Finance 61 (3), 1119-1157.

Holmen, M., Kirchle, M., Kleinlercher, D., (2014). Do Option-like Incentives Induce Overvaluation? Evidence from Experimental Asset Markets, Journal of Economic Dynamics and Control, 40, 179-94.

Holt, C.A., Laury, S.K. (2002). Risk Aversion and Incentive Effects, American Economic Review 92(5), 1644-1655.

Hvide, H.K. (2002). Tournament Rewards and Risk Taking, Journal of Labor Economics 20, 877898.

Isaac, M.R., James, D. (2003). Boundaries of the Tournament Pricing Effect in Asset Markets: Evidence from Experimental Markets, Southern Economic Journal 69 (4), 2003, 936-951.

James, D., Isaac, M.R. (2000). Asset Market Efficiency: the Effects of Tournament Incentives for Individuals, American Economic Review 90, 995-1004.

Kempf, A., Ruenzi, S. (2008). Tournaments in Mutual-Fund Families, Review of Financial Studies $21(2), 1013-1036$.

King, R.R., Smith, V.L., Williams, A.W., Van Boening, M. (1993). The robustness of bubbles and crashes in experimental stock markets. In Day, R., Chen, P. (Eds.), Nonlinear Dynamics and Evolutionary Economics. Oxford: Oxford University Press, 183 -200. 
Kirchler, M., Huber, J., Stöckl, T. (2012). Thar she bursts - Reducing confusion reduces bubbles, American Economic Review, 102(2), 865-883.

Kleinlercher, D., Huber, J., Kirchler, M. (2014), The Impact of Different Incentive Schemes on Asset Prices, European Economic Review, 68, 137-50.

Lee, J. (2004). Prize and Risk-Taking Strategy in Tournaments: Evidence from Professional Poker Players, IZA Working Paper 1345, Bonn.

Lei, V., Noussair, C.N., Plott, C.R. (2001). Nonspeculative Bubbles in Experimental Asset Markets: Lack of Common Knowledge of Rationality vs. Actual Irrationality, Econometrica 69 (4), 831-859.

Lei, V., Vesely, F. (2009). Market efficiency: evidence from a no-bubble asset market experiment, Pacific Economic Review, 14, 246-258.

McLaughlin, K.J. (1988). Aspects of Tournament Models: A Survey, in Research in Labor Economics, JAI Press, 225-256.

Milgrom, P., Stokey, N. (1982). Information, trade and common knowledge, Journal of Economic Theory 26 (1), 17-27.

Niederle, M., Vesterlund, L. (2007). Do Women Shy Away from Competition? Do Men Compete Too Much? The Quarterly Journal of Economics 122 (3), 1067-1101.

Nieken, P. Sliwka, D. (2010). Risk-taking Tournaments - Theory and Experimental Evidence. Journal of Economic Psychology 31 (3), 254-268.

Noussair, C., Robin, S., Ruffieux, B. (2001). Price Bubbles in Laboratory Asset Markets with Constant Intrinsic Values, Experimental Economics 4, 87-105.

Noussair, C., Tucker, S. (2013). Experimental research on asset pricing. Journal of Economic Surveys 27(3), 554-569.

Nuzzo, S., Morone, A. (2017). Asset Markets in the Lab: A Literature Review. Journal of Behavioral and Experimental Finance 13, 42-50.

Oechssler, J., Schmidt, C., Schnedler, W. (2011). On the Ingredients for Bubble Formation: Informed Traders and Communication, Journal of Economic Dynamics and Control 35(11), $1831-1851$.

Palan, S. (2009). Bubbles and Crashes in Experimental Asset Markets, Lecture Notes in Economics and Mathematical Systems, 626, Springer, Heidelberg et al.

Palomino, F. (2005). Relative Performance Objectives in Financial Markets, Journal of Financial Intermediation 14, 351-375.

Powell, M., Ansic, D. (1997). Gender Differences in Risk Behavior in Financial Decision-Making: An Experimental Analysis. Journal of Economic Psychology 18, 605-628.

Powell, O., Shestakova, N., (2016). Experimental Asset Markets: A Survey of Recent Developments. Journal of Behavioral and Experimental Finance 12, 14-22.

Qui, J. (2003). Termination Risk, Multiple Managers and Mutual Fund Tournaments, European Finance Review 7, 161-190. 
Smith, V.L., Suchanek, G.L., Williams, A.W. (1988). Bubbles, Crashes, and Endogenous Expectations in Experimental Spot Asset Markets, Econometrica 56(5), 1119-1151.

Smith, V.L., van Boening, M. Wellford, C.P. (2000). Dividend Timing and Behavior in Laboratory Asset Markets, Economic Theory 16(3), 567-83.

Stöckl, T., Huber, J., Kirchler, M. (2010). Bubble measures in experimental asset markets, Experimental Economics 13, 284-298.

Sutter, M., Huber, J., Kirchler, M. (2012). Bubbles and information : an experiment, Management Science 58, 384-393.

Taylor, J. (2003). Risk-taking behavior in mutual fund tournaments, Journal of Economic Behavior \& Organization 50, 373-383.

Tirole, J. (1982). On the Possibility of Speculation under Rational Expectations, Econometrica 50 (5), 1163-1182.

Van Boening, M. V., Williams, A. W., LaMaster, S. (1993). Price bubbles and crashes in experimental call markets. Economics Letters, 41 (2), 179-185. 


\section{List of tables}

- Table 1. Summary characteristics of mispricing and asset turnover, by treatment

- Table 2. Determinants of price deviations, amplitude and turnover

- Table 3. Individual determinants of activity in the market in various blocks of periods

- Table 4. Determinants of the receipt of bonuses in a period 
Table 1. Summary characteristics of mispricing and asset turnover, by treatment

\begin{tabular}{cccc}
\hline & $\begin{array}{c}\text { No-bonus } \\
\text { treatment }\end{array}$ & $\begin{array}{c}\text { Short-term bonus } \\
\text { treatment }\end{array}$ & $\begin{array}{c}\text { Long-term bonus } \\
\text { treatment }\end{array}$ \\
\hline \hline NAPD & $2.63(2.76)$ & $3.36(3.20)$ & $1.48(1.15)$ \\
NPD & $0.22(0.35)$ & $0.79(1.38)$ & $0.12(0.17)$ \\
Amplitude & $1.05(0.75)$ & $1.87(1.55)$ & $1.05(1.16)$ \\
Turnover & $4.41(2.25)$ & $3.86(1.59)$ & $3.28(1.38)$ \\
Boom Duration & $2.75(2.83)$ & $3.60(2.76)$ & $3.00(2.00)$ \\
\hline
\end{tabular}

Note: The numbers are mean values. Standard deviations are in parentheses. 
Table 2. Determinants of price deviations, amplitude and turnover

\begin{tabular}{|c|c|c|c|}
\hline Dependent variables & $\begin{array}{l}\text { Normalized absolute } \\
\text { price deviation (1) }\end{array}$ & $\begin{array}{l}\text { Amplitude } \\
\text { (2) }\end{array}$ & $\begin{array}{c}\text { Turnover } \\
\text { (3) }\end{array}$ \\
\hline $\begin{array}{l}\text { Short-term bonus } \\
\text { treatment }\end{array}$ & $\begin{array}{c}7.348 \\
(11.221)\end{array}$ & $\begin{array}{c}6.578 \\
(4.589)\end{array}$ & $\begin{array}{c}-16.638 * * \\
(6.888)\end{array}$ \\
\hline $\begin{array}{l}\text { Long-term bonus } \\
\text { treatment }\end{array}$ & $\begin{array}{c}-23.173 * * \\
(10.477)\end{array}$ & $\begin{array}{l}-6.477 \# \\
(4.106)\end{array}$ & $\begin{array}{c}-24.362 * * * \\
(6.839)\end{array}$ \\
\hline Mean safety index & $\begin{array}{l}-2.277^{*} \\
(1.266)\end{array}$ & $\begin{array}{l}-0.756^{*} \\
(0.411)\end{array}$ & $\begin{array}{c}-2.806 * * * \\
(0.730)\end{array}$ \\
\hline $\begin{array}{l}\text { Mean safety index* } \\
\text { short-term bonus treat }\end{array}$ & $\begin{array}{l}-1.829 \\
(1.641)\end{array}$ & $\begin{array}{l}-1.009 \\
(0.722)\end{array}$ & $\begin{array}{l}1.579 \# \\
(0.994)\end{array}$ \\
\hline $\begin{array}{l}\text { Mean safety index* } \\
\text { long-term bonus treat. }\end{array}$ & $\begin{array}{l}2.691^{*} \\
(1.381)\end{array}$ & $\begin{array}{c}0.809 \\
(0.570)\end{array}$ & $\begin{array}{c}2.837 * * * \\
(0.934)\end{array}$ \\
\hline Ratio of male traders & $\begin{array}{l}-8.935^{* *} \\
(4.064)\end{array}$ & $\begin{array}{c}-2.105 * * \\
(0.935)\end{array}$ & $\begin{array}{c}-9.275^{* * *} \\
(1.596)\end{array}$ \\
\hline $\begin{array}{l}\text { Ratio of male traders* } \\
\text { short-term bonus treat. }\end{array}$ & $\begin{array}{l}11.078^{* *} \\
(4.980)\end{array}$ & $\begin{array}{l}1.548 \\
(2.529)\end{array}$ & $\begin{array}{c}10.643 * * * \\
(3.011)\end{array}$ \\
\hline $\begin{array}{l}\text { Ratio of male traders* } \\
\text { long-term bonus treat. }\end{array}$ & $\begin{array}{l}8.753^{*} \\
(4.454)\end{array}$ & $\begin{array}{l}2.039 \\
(2.042)\end{array}$ & $\begin{array}{l}8.261 * * \\
(3.243)\end{array}$ \\
\hline Knowledge in statistics & $\begin{array}{l}-2.074 \# \\
(1.239)\end{array}$ & $\begin{array}{l}-0.750 \\
(0.700)\end{array}$ & $\begin{array}{l}-1.394 * \\
(0.799)\end{array}$ \\
\hline Knowledge in finance & $\begin{array}{c}0.349 \\
(1.056)\end{array}$ & $\begin{array}{l}1.153 \# \\
(0.720)\end{array}$ & $\begin{array}{l}-0.190 \\
(0.660)\end{array}$ \\
\hline Constant & $\begin{array}{c}26.938 * * \\
(10.328)\end{array}$ & $\begin{array}{l}6.737^{*} \\
(3.682)\end{array}$ & $\begin{array}{c}32.115^{* * *} \\
(5.795)\end{array}$ \\
\hline $\mathrm{N}$ & 32 & 32 & 32 \\
\hline $\mathrm{F}$ & 11.84 & 2.80 & 7.78 \\
\hline Prob $>F$ & 0.000 & 0.013 & 0.000 \\
\hline $\mathrm{R}^{2}$ & 0.619 & 0.444 & 0.639 \\
\hline
\end{tabular}

Note: OLS models with robust standard errors clustered at the session level in parentheses. ${ }^{* * *}$ indicates significance at the $1 \%$ level, ** at the $5 \%$ level, * at the $10 \%$ level, \# at the $12 \%$ level. 
Table 3. Individual determinants of activity in the market in various blocks of periods

\begin{tabular}{|c|c|c|c|c|}
\hline $\begin{array}{l}\text { Dependent variable: } \\
\text { Number of } \\
\text { transactions per period }\end{array}$ & $\begin{array}{l}\text { Periods } 1 \text { to } 5 \\
\text { (1) }\end{array}$ & $\begin{array}{l}\text { Periods } 6 \text { to } 10 \\
\text { (2) }\end{array}$ & $\begin{array}{l}\text { Periods } 11 \text { to } 15 \\
\text { (3) }\end{array}$ & $\begin{array}{l}\text { Periods } 1 \text { to } 15 \\
\text { (4) }\end{array}$ \\
\hline $\begin{array}{l}\text { Short-term bonus } \\
\text { treatment }\end{array}$ & $\begin{array}{l}-4.021 \\
(2.643)\end{array}$ & $\begin{array}{l}-4.437 \\
(3.189)\end{array}$ & $\begin{array}{l}-4.878^{*} \\
(2.737)\end{array}$ & $\begin{array}{l}-4.445 \# \\
(2.685)\end{array}$ \\
\hline $\begin{array}{l}\text { Long-term bonus } \\
\text { treatment } \\
\text { Safety index }\end{array}$ & $\begin{array}{c}-5.012 * * \\
(2.465) \\
-0.667 * * \\
(0.299)\end{array}$ & $\begin{array}{l}-6.182 * \\
(3.170) \\
-0.698 * \\
(0.371)\end{array}$ & $\begin{array}{c}-7.024 * * \\
(2.741) \\
-0.669 * \\
(0.334)\end{array}$ & $\begin{array}{l}-6.073 * * \\
(2.591) \\
-0.678 * * \\
(0.317)\end{array}$ \\
\hline $\begin{array}{l}\text { Safety index * } \\
\text { short-term bonus treat. }\end{array}$ & $\begin{array}{c}0.094 \\
(0.185)\end{array}$ & $\begin{array}{c}0.145 \\
(0.206)\end{array}$ & $\begin{array}{c}0.236 \\
(0.179)\end{array}$ & $\begin{array}{c}0.159 \\
(0.179)\end{array}$ \\
\hline $\begin{array}{l}\text { Safety index * } \\
\text { long-term bonus treat. } \\
\text { Male }\end{array}$ & $\begin{array}{c}1.605^{*} \\
(0.838) \\
-1.617 * * \\
(0.620)\end{array}$ & $\begin{array}{c}0.179 \\
(0.135) \\
-1.431 * * \\
(0.681)\end{array}$ & $\begin{array}{l}0.216^{*} \\
(0.118) \\
-1.042 \# \\
(0.652)\end{array}$ & $\begin{array}{c}0.170 \\
(0.115) \\
-1.363 * * \\
(0.571)\end{array}$ \\
\hline $\begin{array}{l}\text { Male * } \\
\text { short-term bonus treat. }\end{array}$ & $\begin{array}{c}2.471 * * * \\
(0.880)\end{array}$ & $\begin{array}{c}2.857 * * * \\
(0.916)\end{array}$ & $\begin{array}{c}2.630^{* *} \\
(1.020)\end{array}$ & $\begin{array}{c}2.653 * * * \\
(0.784)\end{array}$ \\
\hline $\begin{array}{l}\text { Male * } \\
\text { long-term bonus treat. } \\
\text { Knowledge in statistics }\end{array}$ & $\begin{array}{c}1.605^{*} \\
(0.838) \\
0.065 \\
(0.165)\end{array}$ & $\begin{array}{l}1.590^{*} \\
(0.822) \\
-0.043 \\
(0.220)\end{array}$ & $\begin{array}{c}1.799 * * \\
(0.837) \\
0.174 \\
(0.184)\end{array}$ & $\begin{array}{c}1.665 * * \\
(0.731) \\
0.065 \\
(0.144)\end{array}$ \\
\hline $\begin{array}{l}\text { Knowledge in finance } \\
\text { Constant }\end{array}$ & $\begin{array}{c}-0.552 * * \\
(0.244) \\
13.679 * * * \\
(2.284)\end{array}$ & $\begin{array}{c}-0.149 \\
(0.194) \\
11.590 * * * \\
(3.014)\end{array}$ & $\begin{array}{c}-0.272 * \\
(0.141) \\
10.148 * * * \\
(2.511)\end{array}$ & $\begin{array}{c}-0.324 * \\
(0.164) \\
11.806 * * * \\
(2.477)\end{array}$ \\
\hline $\mathrm{N}$ & 1280 & 1280 & 1280 & 3840 \\
\hline F & 4.42 & 1.99 & 3.10 & 2.74 \\
\hline Prob $>F$ & 0.001 & 0.069 & 0.008 & 0.015 \\
\hline $\mathrm{R}^{2}$ & 0.070 & 0.055 & 0.055 & 0.052 \\
\hline
\end{tabular}


Table 4. Determinants of the receipt of bonuses in a period

\begin{tabular}{|c|c|c|c|c|c|}
\hline \multirow{2}{*}{$\begin{array}{l}\text { Dependent variable: } \\
\text { Amount of bonus } \\
\text { earned }\end{array}$} & \multicolumn{4}{|c|}{ Short-term bonus treatment } & \multirow{2}{*}{$\begin{array}{l}\text { Long-term } \\
\text { bonus } \\
\text { treatment ( } 5)\end{array}$} \\
\hline & $\begin{array}{l}\text { Periods } 1-5 \\
\text { (1) }\end{array}$ & $\begin{array}{c}\text { Periods } 6-10 \\
\text { (2) }\end{array}$ & $\begin{array}{c}\text { Periods } 11-15 \\
\text { (3) }\end{array}$ & $\begin{array}{c}\text { Periods } 1-15 \\
\text { (4) }\end{array}$ & \\
\hline Safety Index & $\begin{array}{c}0.128 * * * \\
(0.037)\end{array}$ & $\begin{array}{c}0.074 * * * \\
(0.029)\end{array}$ & $\begin{array}{c}0.005 \\
(0.022)\end{array}$ & $\begin{array}{c}0.067 * * * \\
(0.013)\end{array}$ & $\begin{array}{c}0.064 \\
(0.070)\end{array}$ \\
\hline Male & $\begin{array}{c}0.357 * * \\
(0.159)\end{array}$ & $\begin{array}{c}0.370 * * \\
(0.182)\end{array}$ & $\begin{array}{c}0.039 \\
(0.170)\end{array}$ & $\begin{array}{c}0.248 * * \\
(0.102)\end{array}$ & $\begin{array}{c}0.001 \\
(0.334)\end{array}$ \\
\hline $\begin{array}{l}\text { Knowledge in } \\
\text { statistics }\end{array}$ & $\begin{array}{c}0.018 \\
(0.124)\end{array}$ & $\begin{array}{c}0.063 \\
(0.067)\end{array}$ & $\begin{array}{c}-0.060 \\
(0.055)\end{array}$ & $\begin{array}{c}0.006 \\
(0.062)\end{array}$ & $\begin{array}{c}0.318 \\
(0.219)\end{array}$ \\
\hline $\begin{array}{l}\text { Knowledge in } \\
\text { finance }\end{array}$ & $\begin{array}{c}0.067 \\
(0.076)\end{array}$ & $\begin{array}{l}-0.040 \\
(0.066)\end{array}$ & $\begin{array}{l}-0.023 \\
(0.036)\end{array}$ & $\begin{array}{c}0.001 \\
(0.048)\end{array}$ & $\begin{array}{l}-0.117 \\
(0.173)\end{array}$ \\
\hline $\begin{array}{l}\mathrm{N} \\
\text { Wald chi } \\
\text { Prob }>\text { chi }^{2} \\
\text { Pseudo } \mathrm{R}^{2} \\
\text { log pseudo-likelihood }\end{array}$ & $\begin{array}{c}400 \\
23.85 \\
0.000 \\
0.035 \\
-414.347\end{array}$ & $\begin{array}{c}400 \\
15.27 \\
0.004 \\
0.020 \\
-420.804\end{array}$ & $\begin{array}{c}400 \\
2.99 \\
0.560 \\
<0.001 \\
-428.346\end{array}$ & $\begin{array}{c}1200 \\
30.60 \\
0.000 \\
0.011 \\
-1274.705\end{array}$ & $\begin{array}{c}80 \\
3.36 \\
0.499 \\
0.029 \\
-83.388\end{array}$ \\
\hline
\end{tabular}

Note: Ordered probit models, with robust standard errors clustered at the session level in parentheses. $* * *$ indicate significance at the $1 \%$ level and $* *$ at the $5 \%$ level. 


\section{List of Figures}

- Figure 1. Evolution of the intrinsic value of an asset over time

- Figure 2. Evolution of the median price over time, by treatment

- Figure 3. Evolution of the mean volume of trade per period for different blocks of periods, by treatment 


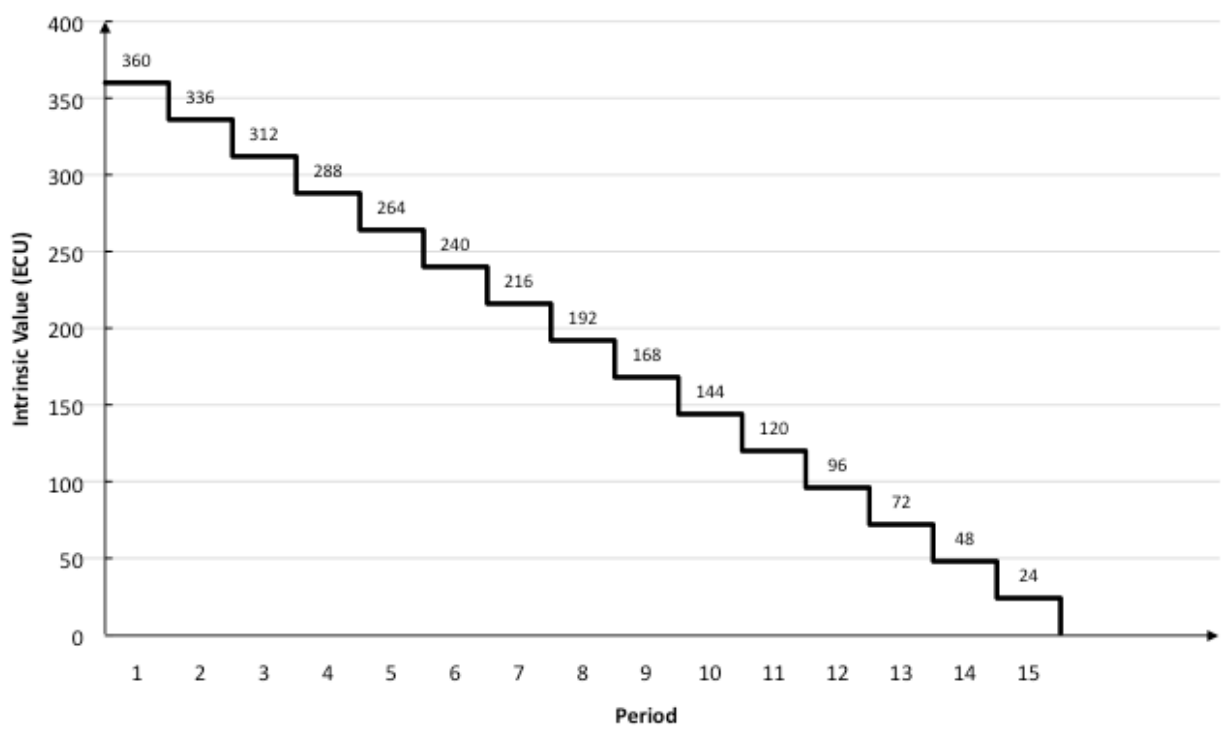

Figure 2. Evolution of the intrinsic value of an asset over time. 


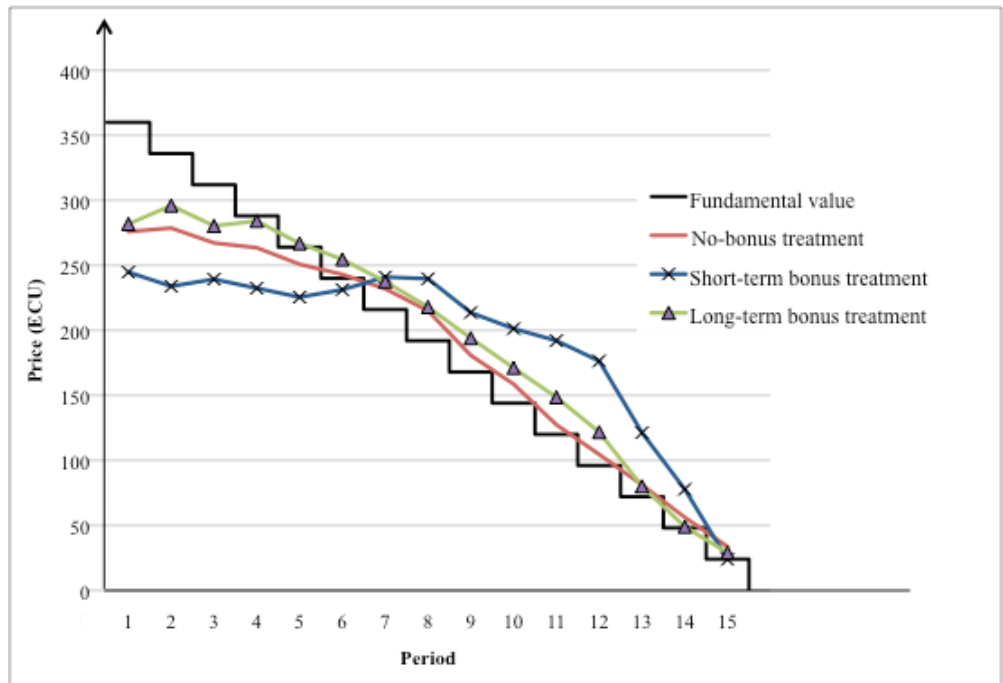

Figure 2. Evolution of the median price over time, by treatment 


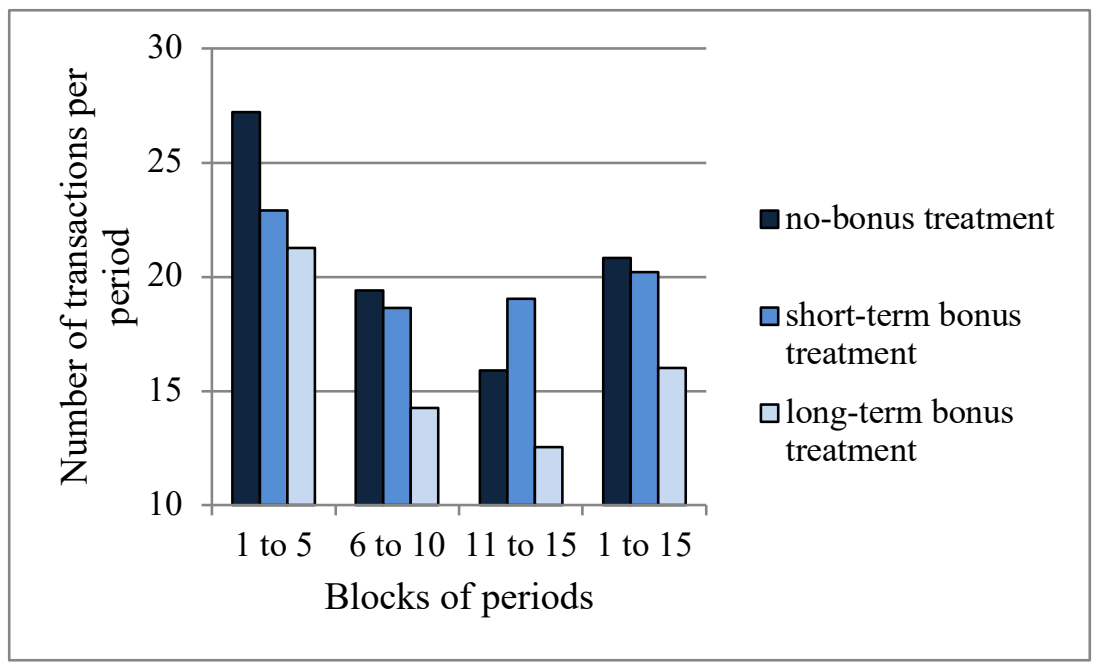

Figure 3. Evolution of the mean volume of trade per period for different blocks of periods, by treatment 


\section{APPENDIX A - Instructions (Translated from French)}

Welcome and thank you for participating in our experiment on decision-making in economics. Please to not talk or communicate with the other participants during the experiment. You have received the instructions for the first part of the experiment. The instructions for the second part will be distributed after part 1 has been completed.

\section{Part 1}

Thank you for answering this questionnaire. Your answers will bring you a sum of money that will be paid to you with your other earnings at the end of the experiment. We present you a sheet with ten decisions to make. Each decision is a paired choice between two options: "Option A" and "Option B". You will make ten choices and record them in the column on the right side. Only one of your choices will be used in the end to determine your final earnings for this questionnaire.

We use a ten-sided die for determining the payoffs. The faces are numbered from 1 to 10 (the « $0 »$ face of the die will serve as number « $10 »)$. At the end of the experiment when receiving your final earnings, you will throw the dice twice.

- Once to select one of the ten decisions to be used,

- A second time to determine what your earning is for the option you chose, «Option A » or «Option B », for the particular decision selected.

Even though you will make ten decisions, only one of these will really affect your final earnings. Nevertheless you will not know in advance which decision will be selected. Of course, each decision has an equal chance of being used.

- Look at decision 1.

The option A pays $2 €$ if the throw of the ten-sided die is 1 , and it pays $1,6 €$ if the throw is between 2 and 10 .

The option B pays $3,85 €$ if the throw of the ten-sided die is 1 , and it pays $0.1 €$ if the throw is between 2 and 10 .

- Look at decision 2.

The option A pays $2 €$ if the throw of the ten-sided die is 1 or 2 , and it pays $1.6 €$ if the throw is between 3 and 10 .

The option B pays $3.85 €$ if the throw of the ten-sided die is 1 or 2 , and it pays $0.1 €$ if the throw is between 3 and 10 .

The other decisions are similar, except that as you move down the table, the chances of the higher payoff for each option increase. In fact, for decision 10 in the bottom row, the die will not be needed since each option pays the highest payoff for sure. Therefore, in this decision row you make a choice between $2 €$ et $3.85 €$.

To summarize:

You will make ten choices now. For each decision row you are asked to make a choice between Option A and Option B. You may choose the option A for some decisions and the option B for other rows. You may change your decisions and make them in any order.

At the end of the session, you will roll the ten-sided die to select which of the ten decisions will be used. Then, you will roll the die again to determine your money earnings for the option you chose for the selected decision. Earning for this choice will be added to your other earnings, and will be paid to you in cash at the end of the experiment.

Should you have any question, please raise your hand and we will come to you and answer your questions in private. Please do not communicate with the other participants. 
Please make now your choices and record for each of the ten decision rows whether you prefer the option $A$ or the option $B$.

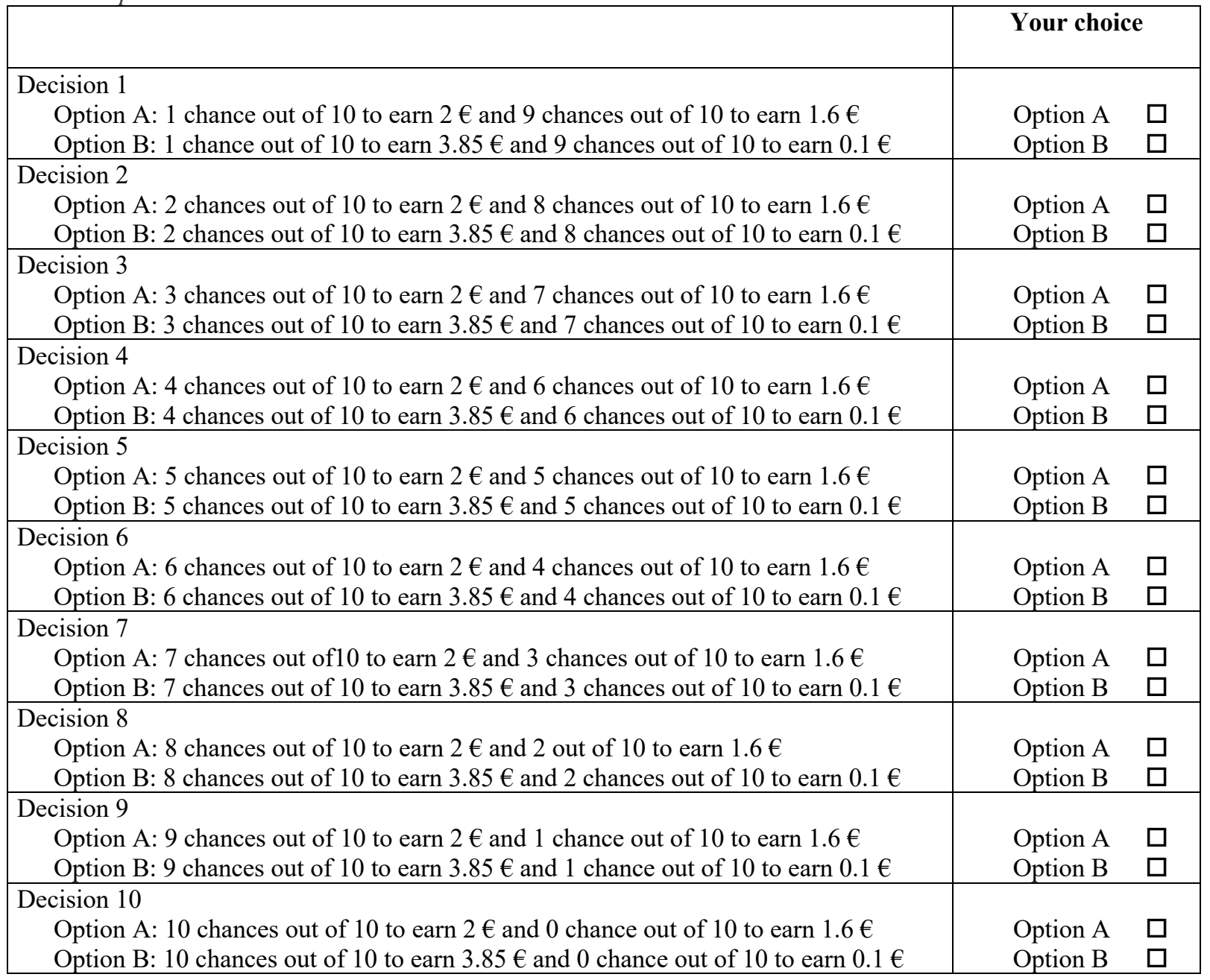




\section{Part 2 (These instructions were distributed after Part 1 was completed)}

The instructions for this game are simple, and if you follow them carefully and make good decisions, you may earn a considerable amount of money that will be paid to you in cash at the end of session. Your gains will be converted into Euros at the following exchange rate:

$$
\begin{gathered}
300 \mathrm{ECU}=€ 1 \\
\text { or } 1 \mathrm{ECU}=€ 0,0033
\end{gathered}
$$

In addition to your gains, you will receive a show-up fee of 5 Euro. All money you earn will be paid to you, privately and in cash, at the end of experiment. If you realize a loss at the end of experiment, its amount will be deducted from your show-up fee.

The market experiment consists of a sequence of 15 trading periods, in which you have the opportunity to buy and sell assets. At the end of each period, the units of assets everybody holds generate a gain that will be determined by a lottery. The rules of the lottery will be explained further in the text. Including you, there are eight participants in this market. The good called " $X$ " may be considered as an asset of life of 15 trading periods.

At the beginning of each period, every participant is provided with an endowment of 10 units of good $X$. For every participant her inventory of X carries over from one trading period to the next. At the end of each period, each unit of an asset in your holdings generates a dividend payment. The amount of the dividend is determined by a random draw.

- If the random draw equals 0 , you earn 0 ECU for each unit of X you hold

- $\quad$ If the random draw equals 8 , you earn $8 \mathrm{ECU}$ for each unit of X you hold

- If the random draw equals 28 , you earn $28 \mathrm{ECU}$ for each unit of X you hold

- If the random draw equals 60, you earn $60 \mathrm{ECU}$ for each unit of $\mathrm{X}$ you hold

The dividend payment in a given period is common to all participants. Each of the four earnings is equally likely. Therefore, the average dividend payment per asset in one period is 24 ECU (i.e. $1 / 4 * 0+$ $1 / 4 * 8+1 / 4 * 28+1 / 4 * 60=24 \mathrm{ECU})$.

Each trading period lasts four minutes. During each trading period you may either sell part of your holdings of assets or you may alternatively use your cash endowments to purchase more assets.

\section{Market organization}

\section{How to sell in the market?}

There are two ways to sell asset holdings in the market:

- The first one consists of making an offer to sell and letting it be accepted by another participant in the market.

- The second one consists of accepting an offer to buy that was made by another participant in the market.

- An offer to sell appears on the market if and only if its price is inferior to the price of the offer to sell that is currently displayed on the market.

\section{How to buy in the market?}

There are two ways to buy units of assets in the market:

- The first one consists of making an offer to buy and letting it be accepted by another participant in the market.

- The second one consists of accepting an offer to sell that was made by another participant in the market.

- An offer to buy appears on the market if and only if its price is superior to the price of the offer to buy that is currently displayed in the market. 
At the beginning of the game, every participant is provided with a cash endowment of 20,000 ECU. Note that this cash endowment represents a loan that you will give back at the end of the experiment. Sales of your asset holdings increase your cash balance by the amount of the sale price. Similarly, purchases reduce your cash balance by the amount of the purchase price.

Thus, you can gain or lose money on the purchase and sale of your asset holdings. The trading system will automatically update your cash balance and asset holdings to reflect your purchases and/or sales. Your cash balance is carried over from one trading period to the next. At the end of the experiment you will pay the loan of 20,000 ECU back to calculate your final earnings. You cannot buy good X when you do not have any cash. Just as you cannot sell any units of good $\mathrm{X}$ if you do not have any units of good $\mathrm{X}$ in your holding.

\section{The average holding value of a unit from period to period}

You can use your average holding value table to help you make decisions that is in annex A of these instructions. There are 4 columns in the table.

The first column, labeled Current Period, indicates the period during which the average holding value is being calculated.

The second column, labeled Number of Remaining Periods, gives the number of holding periods from the period in the first column until the end of the experiment.

The third column, labeled Average Holding Value per Period, indicates the average amount of your earnings in each period for each unit held in your inventory. The Average Holding Value equals 24 ECU.

The fourth column, labeled Average Holding Value per Unit of Inventory, gives the average value for each unit hold in your inventory from now until the end of the experiment. The Average Holding Value per Unit of Inventory equals the Average Holding Value per Period, i.e. 24 ECU, multiplied by the number of remaining periods.

At the end of the last period, period 15, the last dividend payment takes place. After this dividend payment, the units of asset are worth nothing.

Example 1: Suppose that the current period is the period 8. Then there are 7 periods remaining until the end of the experiment. There are still 8 dividend payments remaining for the experiment (one payment for the current period and 7 payments for the periods from 9 to 15). The average holding value per period is 24 ECU. The Average Holding Value per Unit of Inventory until the end of the experiment is $8 * 24=192$ ECU.

\section{Period Profits}

In every period your profit equals the difference in cash coming from the gains and losses from purchasing and selling units of good X plus your earnings generated by the dividend payments of all units of good X you hold at the end of the period.

Example 2: Suppose that at the beginning of one period you possess $20950 \mathrm{ECU}$ in cash and 11 units of good X. Suppose that during this period you sell one unit of good X for $250 \mathrm{ECU}$. At the end of this period, your hold $21200 \mathrm{ECU}$ in cash $(20950+250)$ and 10 units of good X. Finally, suppose that the average holding value drawn in this period is $28 \mathrm{ECU}$.

Then your profit in this period will be $(21200-20950)+10 * 28=530 \mathrm{ECU}$.

\section{Bonus determination}

Besides your period profit, you may receive a bonus. The bonus is given to the three market participants who have realized the highest performance within a period. In each period, the performance calculation 
depends on the period profit and the evolution of the value of your asset holdings, taking into consideration the transaction prices observed in the market.

The evolution of the assets' value within a period is calculated as a difference between the value of the asset at the end of the period and its value at the beginning of the period. The stock value at the end of period equals the number of assets you hold at the end of the period multiplied by the average transaction price in the current period. The stock value at the beginning of the period equals the number of the assets you hold at the beginning of the period multiplied by the average transaction price during the previous period.

Example 3: Suppose that the average transaction price in the previous period was $150 \mathrm{ECU}$ and that at the beginning of the period you hold 6 units. Suppose that the average transaction price in the current period is $160 \mathrm{ECU}$ and that at the end of this period you hold 7 units.

The evolution of the value of your stock is than $220 \mathrm{ECU}(160 * 7-150 * 6)$.

Note: the value of your stock according to the market price

- increases when the market price increases or when the number of units you hold increases,

- decreases when the market price decreases or when the number of units you hold decreases.

In each period, your performance equals the sum of your profit and the evolution of the value of your stock according to the market price.

Example 4: Suppose that your profit in the period is 530 ECU. Suppose that the evolution of your stock is $220 \mathrm{ECU}$. Your performance in this period is $750 \mathrm{ECU}$.

Note: in the first period, as there is no previous period, the performance equals the sum of your profit and the value of the stock at the end of the first period (which is the number of asset holdings at the end of the first period multiplied by the average transaction price in the first period).

The program compares the performance of all market participants at the end of each period.

- The participant who realized the highest performance among the eight participants receives a bonus of 240 ECU.

- The participant who realized the second highest performance among the eight participants receives a bonus of 168 ECU.

- The participant who realized the third highest performance among the eight participants receives a bonus of 72 ECU.

- The five other participants receive no bonus (0 ECU).

In case of ties, the computer program draws randomly the participant who will receive the bonus among the ties. The participants are informed about the bonus they receive but do not know if there was a random draw.

\section{Recording your earning}

At the end of each period, a feedback on the outcomes in this period will be displayed on your computer screen. You are also requested to record your period earnings on the earning sheet in the Appendix of these instructions, using the information displayed on your screen.

Please find below a copy of the screen displaying the outcomes at the end of each period. Information of each period is displayed on two consecutive screens (profit and bonus). 
YOUR PROFIT IN THIS PERIOD

$\begin{array}{lc}\begin{array}{r}\text { Your wealth at the end of this period: } \\ \text { Your wealth at the beginning of this period: }\end{array} & 21776 \\ \begin{array}{l}\text { Difference in wealth (end - beginning of this period): } \\ \text { Number of shares at the end of this period: }\end{array} & 1776 \\ \text { Dividend per share: } & 28 \\ \text { Total Dividends: } & 224 \\ \\ \text { Your profit in this period: }\end{array}$

BONUS ATTRIBUTION IN THIS PERIOD

Your profit in this period: 2000

Your stock at the end of this period: $\quad 8$

Average price per share in this period: $\quad 888$

Value of your stock at the end of this period: $\quad 7104$

Number of your stock at the beginning of this period: $\quad 0$

Average price per share in the previous period: $\quad 0$

Value of your stock at the beginning of this period: $\quad 0$

Evolution of the value of your stock: $\quad 7104$

Amount of your bonus in this period: $\quad 168$

The three best performers received a bonus.

The best performer received a bonus of $240 \mathrm{ECU}$.

The second best performer received a bonus of $168 \mathrm{ECU}$ and the third best performer received a bonus of $72 \mathrm{ECU}$.

Your total earnings in this period: $\quad 2168$ 


\section{Practice period}

Before the experiment starts, you will practice the game during 5 minutes. During this practice period you will familiarize yourselves with the market rules and the program. All transactions made during the practice period have no consequence on your final payoff. At the end of the practice period your endowments in cash and units of good $\mathrm{X}$ will be reinitialized.

Are there any questions about what has been said until now? Please raise your hand if you have any question and we will answer your questions in private. 


\section{APPENDIX B - Measures of bubble severity}

The normalized absolute price deviation (NAPD) measures the per-share aggregate overvaluation (or undervaluation) relative to the asset fundamental value in a given period. It accounts for both transaction prices and traded quantities. It is defined as follows:

$$
N R A D=\sum_{t} \sum_{i}\left|p_{i t}-f_{t}\right| /(100 \cdot T S U)
$$

where $P_{i t}$ denotes the price of the $i^{t h}$ actual trade in period $t, f_{t}$ is the asset's fundamental value in period $t$ and TSU is the total sum of asset holdings (80 in our experiment). Since a high price deviation reflects high trading volumes and deviations from fundamental values, it also indicates the occurrence of a bubble.

The normalized price deviation (NPD) is similar to NAPD, but instead of considering absolute price deviations, it relies on raw price deviations. It is defined as follows:

$$
N P D=\sum_{t} \sum_{i}\left(p_{i t}-f\right) /(100 \cdot T S U)
$$

A positive value of NPD indicates that the market on average overvalues the asset, whereas a negative value indicates undervaluation.

The amplitude measures the magnitude of the overall price changes relative to the asset's fundamental value over its life. It is defined as:

$$
\text { Amplitude }=\max _{t}\left(\left(\bar{P}_{t}-f_{t}\right) / f_{t}\right)-\min _{t}\left(\left(\bar{P}_{t}-f_{t}\right) / f_{t}\right)
$$

where $\bar{P}_{t}$ is the mean transaction price in period $t$, and $f_{t}$ is the fundamental value in period $t$.

Turnover measures the trading activity throughout the market session relative to the total sum of asset holdings. It is defined as follows:

$$
\text { Turnover }=\sum_{t} q_{t} / T S U
$$

where $q_{\mathrm{t}}$ is the number of traded assets in period $t$. In markets where traders' rationality is common knowledge, risk-aversion would be the only factor motivating trading. For this reason, high turnover is considered as an indicator of a price bubble.

The boom duration represents the number of consecutive periods where the market median price is superior to the asset fundamental value by at least $20 \%$. 


\section{APPENDIX C. Descriptive statistics by treatment and by session}

Table $\mathrm{C} 1$. Measures of bubble intensity and risk attitudes by session in the No-bonus treatment

\begin{tabular}{|c|c|c|c|c|c|c|c|c|c|}
\hline Session & NAPD & NPD & Amp. & Turnover & $\begin{array}{l}\text { Total nb } \\
\text { of trades }\end{array}$ & $\begin{array}{c}\text { Total } \\
\text { dispersion }\end{array}$ & $\begin{array}{l}\text { Average } \\
\text { distortion }\end{array}$ & $\begin{array}{l}\text { Mean safety } \\
\text { index HL }\end{array}$ & $\begin{array}{l}\text { SD safety } \\
\text { index HL }\end{array}$ \\
\hline 1 & 1.08 & 1.04 & 0.93 & 2.15 & 172 & 687.00 & 43.33 & 7.13 & 1.89 \\
\hline 18 & 7.56 & 0.00 & 2.36 & 8.30 & 664 & 1204.00 & -9.67 & 6.13 & 1.13 \\
\hline 19 & 1.07 & 0.71 & 0.44 & 3.45 & 276 & 342.00 & 18.00 & 7.25 & 1.28 \\
\hline 20 & 1.30 & -0.01 & 1.32 & 5.56 & 445 & 151.50 & 0.10 & 7.00 & 1.60 \\
\hline 21 & 0.62 & 0.34 & 0.58 & 2.41 & 193 & 353.50 & 22.23 & 7.75 & 1.28 \\
\hline 22 & 0.25 & 0.21 & 0.14 & 2.26 & 181 & 107.50 & 7.03 & 7.38 & 1.60 \\
\hline 23 & 0.61 & -0.01 & 0.26 & 3.16 & 253 & 177.50 & -3.93 & 6.63 & 1.19 \\
\hline 24 & 7.33 & 0.00 & 1.72 & 7.25 & 580 & 1371.50 & -10.37 & 7.38 & 1.41 \\
\hline 25 & 2.28 & 0.00 & 2.39 & 6.03 & 482 & 426.00 & 4.87 & 6.38 & 1.30 \\
\hline 26 & 6.37 & 0.00 & 0.83 & 6.83 & 546 & 1561.50 & -14.00 & 7.25 & 1.16 \\
\hline 27 & 0.96 & 0.42 & 0.85 & 2.08 & 166 & 665.00 & 35.40 & 7.75 & 1.28 \\
\hline 28 & 2.20 & -0.01 & 0.75 & 3.48 & 278 & 428.50 & -12.00 & 6.38 & 2.13 \\
\hline Mean & 2.63 & 0.22 & 1.05 & 4.41 & 353 & 622.96 & 6.75 & 7.03 & 1.44 \\
\hline Stand. Dev. & 2.76 & 0.35 & 0.75 & 2.25 & 179.66 & 495.36 & 19.15 & 0.54 & 0.31 \\
\hline Median & 1.19 & 0.00 & 0.84 & 3.46 & 277 & 427.25 & 2.48 & 7.19 & 1.29 \\
\hline Min. & 0.25 & -0.01 & 0.14 & 2.08 & 166 & 107.50 & -14.00 & 6.13 & 1.13 \\
\hline Max. & 1.08 & 1.04 & 0.93 & 2.15 & 172 & 687.00 & 43.33 & 7.13 & 1.89 \\
\hline
\end{tabular}

Note: NAPD, NPD, amplitude and turnover are defined in Appendix B.

Total Dispersion $=\sum_{t} \mid$ Median $P_{t}-f_{t} \mid$ where Median $P_{t}$ represents the median price of concluded transactions in period $t$ and $f_{t}$ represents the fundamental value of the asset in period $t$.

Average Distortion $=\sum_{t}\left(\right.$ Median $\left.P_{t}-f_{t}\right) / 15$ It indicates the average deviation of the period median price from the asset intrinsic value over the 15 periods.

HL holds for Holt and Laury test and SD for standard deviation. The mean safety index is defined as the switching point in the lottery choices. 
Table C2. Measures of bubble intensity and risk attitudes by session in the short-term bonus treatment

\begin{tabular}{rrrrrrrrrr}
\hline \multicolumn{1}{r}{ Session } & NAPD & NPD & Amp. & Turnover & $\begin{array}{c}\text { Nb of } \\
\text { trades }\end{array}$ & $\begin{array}{r}\text { Total } \\
\text { dispersion }\end{array}$ & $\begin{array}{c}\text { Average } \\
\text { distortion }\end{array}$ & $\begin{array}{c}\text { Mean safety } \\
\text { index HL }\end{array}$ & $\begin{array}{c}\text { SD safety } \\
\text { index HL }\end{array}$ \\
\hline 2 & 0.16 & 0.03 & 0.62 & 1.61 & 129 & 99.50 & 0.93 & 7.25 & 1.04 \\
3 & 1.41 & 0.43 & 1.92 & 2.41 & 193 & 1013.50 & 44.50 & 6.75 & 1.28 \\
4 & 4.64 & -0.04 & 2.54 & 4.01 & 321 & 1633.00 & -20.47 & 6.13 & 2.17 \\
5 & 1.55 & 0.00 & 0.85 & 4.10 & 328 & 476.00 & -2.20 & 6.75 & 1.98 \\
7 & 5.36 & 3.59 & 4.36 & 6.24 & 499 & 1281.00 & 56.87 & 6.75 & 1.91 \\
8 & 8.49 & 3.10 & 4.32 & 4.33 & 346 & 2958.00 & 78.33 & 6.25 & 2.71 \\
12 & 1.47 & 0.75 & 0.71 & 3.38 & 270 & 403.50 & 14.47 & 6.75 & 1.83 \\
13 & 0.13 & 0.06 & 0.18 & 1.88 & 150 & 75.50 & 4.20 & 7.50 & 1.07 \\
17 & 8.51 & 0.00 & 2.59 & 6.10 & 488 & 1790.50 & -18.67 & 5.50 & 3.25 \\
32 & 1.84 & -0.04 & 0.56 & 4.56 & 365 & 455.50 & -4.37 & 7.00 & 1.31 \\
\hline Mean & 3.36 & 0.79 & 1.87 & 3.86 & 308.90 & 1018.60 & 15.36 & 6.66 & 1.85 \\
Stand. Dev. & 3.20 & 1.38 & 1.55 & 1.59 & 127.28 & 914.54 & 33.35 & 0.58 & 0.72 \\
Median & 1.69 & 0.05 & 1.38 & 4.06 & 324.50 & 744.75 & 2.57 & 6.75 & 1.87 \\
Min. & 0.13 & -0.04 & 0.18 & 1.61 & 129.00 & 75.50 & -20.47 & 5.50 & 1.04 \\
Max. & 8.51 & 3.59 & 4.36 & 6.24 & 499.00 & 2958.00 & 78.33 & 7.50 & 3.25 \\
\hline
\end{tabular}

Note: See note below Table $\mathrm{C} 1$ for definitions.

Table C3. Measures of bubble intensity and risk attitudes by session in the long-term bonus treatment

\begin{tabular}{|c|c|c|c|c|c|c|c|c|c|}
\hline Session & NAPD & NPD & Amp. & Turnover & $\begin{array}{l}\mathrm{Nb} \text { of } \\
\text { trades }\end{array}$ & $\begin{array}{c}\text { Total } \\
\text { dispersion }\end{array}$ & $\begin{array}{l}\text { Average } \\
\text { distortion }\end{array}$ & $\begin{array}{l}\text { Mean safety } \\
\text { index HL }\end{array}$ & $\begin{array}{l}\text { SD safety } \\
\text { index HL }\end{array}$ \\
\hline 6 & 0.60 & 0.46 & 0.36 & 3.03 & 242.00 & 233.00 & 14.20 & 6.00 & 2.20 \\
\hline 9 & 1.41 & 0.00 & 0.99 & 3.04 & 243.00 & 721.00 & -6.33 & 6.63 & 2.07 \\
\hline 10 & 0.49 & 0.19 & 0.46 & 2.41 & 193.00 & 305.00 & 18.13 & 6.50 & 2.33 \\
\hline 11 & 0.31 & 0.02 & 0.38 & 2.26 & 181.00 & 154.50 & 4.70 & 5.63 & 1.51 \\
\hline 14 & 0.37 & 0.35 & 0.31 & 1.63 & 130.00 & 195.50 & 12.47 & 6.13 & 1.36 \\
\hline 15 & 1.42 & 0.00 & 0.65 & 2.58 & 206.00 & 551.00 & 8.27 & 6.88 & 2.30 \\
\hline 16 & 3.90 & 0.00 & 1.76 & 6.09 & 487.00 & 844.50 & 11.23 & 7.13 & 1.55 \\
\hline 29 & 1.53 & 0.00 & 0.59 & 4.13 & 330.00 & 406.50 & 3.43 & 4.75 & 2.76 \\
\hline 31 & 2.18 & -0.02 & 4.10 & 2.68 & 214.00 & 1180.00 & -10.67 & 5.50 & 2.73 \\
\hline 33 & 2.58 & 0.20 & 0.89 & 5.00 & 400.00 & 515.00 & 8.63 & 5.13 & 1.46 \\
\hline Mean & 1.48 & 0.12 & 1.05 & 3.28 & 262.60 & 510.60 & 6.41 & 6.03 & 2.03 \\
\hline $\begin{array}{r}\text { Stand. } \\
\text { Dev. }\end{array}$ & 1.15 & 0.17 & 1.16 & 1.38 & 110.17 & 326.90 & 9.02 & 0.77 & 0.53 \\
\hline Median & 1.41 & 0.01 & 0.62 & 2.85 & 228.00 & 460.75 & 8.45 & 6.06 & 2.13 \\
\hline Min. & 0.31 & -0.02 & 0.31 & 1.63 & 130.00 & 154.50 & -10.67 & 4.75 & 1.36 \\
\hline Max. & 3.90 & 0.46 & 4.10 & 6.09 & 487.00 & 1180.00 & 18.13 & 7.13 & 2.76 \\
\hline
\end{tabular}

Note: See note below Table $\mathrm{C} 1$ for definitions. 